\title{
MÚSICA, INSTRUMENTOS Y DANZAS EN LAS OBRAS DE CERVANTES
}

\section{1}

Miguel de Cervantes hace, como se sabe, frecuentes referencias a la música y a las danzas en casi todas sus obras. Se han estudiado por algunos escritores las menciones que de una y otras hace Cervantes en Don Quijote, y los especialistas en asuntos cervantinos han comentado reiteradamente esas referencias en sus ediciones. Puesto que se ofrece ahora ocasión para ello, se reunirán en este trabajo todas aquellas referencias, desde la Galatea al Persiles, en la creencia de que algunos puntos de vista que ahora se exponen difieren de los acostumbrados. Las referencias a música y danzas en Cervantes son de diversa índole, de acuerdo con la obra o el pasaje en que se presentan: las más veces como complemento indispensable para pintar el ambiente, sea el paisaje pastoril en las obras que acabo de mencionar, sea el medio ciudadano, descrito"con tan agudo realismo, de las Novelas ejemplares y los Entremeses. En la obra magna de Cervantes intervienen ambos aspectos: ya son danzas, perfectamente organizadas, con ocasión de las bodas de Camacho, en pasajes donde Cervantes recuerda su primera disciplina literaria, que fué la égloga y la novela pastoril, o bien son alusiones a la música cotidiana en la vida del Caballero.

La primera y más neta distinción consiste en que en las obras del tipo pastoril Cervantes hace referencia a danzas e instrumentos que conoce principalmente por estar mencionados en las obras del mismo género de sus predecesores; mientras que en las Novelas, Comedias y Entremeses se refiere a cosas que está viendo y escuchando cada día. Una cosa son los pastores que aparecen en los libros, tañendo, cantando y danzando, y otra cosa son las fregonas, rufianes, pícaros, mozas de mesón, farsantes y barberos filarmónicos. Dos zonas, pues, de arte a las que corresponden sendos tipos de músicas, danzas e instrumentos. En el primer caso, Cervantes procede con cautela en sus citaciones. Conoce bien obras en las que, como en las Dianas de Jorge de Montemayor y de Gil Polo, aparece todo el aparato pastoril I que, en ellos, se combina en juegos de una gracia e imaginación a los que no se arriesga Cervantes. No sólo porque no era músico que hablara de lo que sabía practicar, como Gil Vicente en.sus Autos y Farsas, o Montemayor en la Diana, sino porque no muestra gusto ni inclinación en ninguno de sus escritos por adentrarse en las zonas de cierta elevación en la música de su siglo, que es, justamente, el siglo de oro de la música española; al paso que en las obras de carácter realista y de episodios que pudo ver cotidianamente, muestra un buen conocimiento de las costumbres de su tiempo. No tanto

I Las llamadas en números romanos corresponden a las Anotaciones que aparecerán al final de la segunda parte de este artículo, en el número próximo de NRFH. 
las señoriales o de rango burgués, como, preferentemente, las del pueblo, y tanta mayor puntualidad hay en sus menciones cuanto más bajo es el nivel de las zonas populares que pinta con tan agudos rasgos y firme colorido.

Si Cervantes no se interesa por sus grandes contemporáneos en el arte musical, tampoco, es verdad, le preocupa mucho el arte pictórico de su tiempo, y si bien menciona por sus nombres a los autores de determinadas obras literarias no se pára a decirnos quién es el músico de las estancias de Ariosto que canta don Quijote ni el pintor famoso del retrato de Auristela. No por ignorancia de quiénes fuesen los más notables artífices de la antiguiedad ni de su tiempo, pues que cuando Hipólita muestra a Periandro (en el libro Iv, capítulo vir, de los Trabajos de Persiles y Sigismunda) la sala donde guarda obras maestras de la antigua y moderna pintura, esas obras eran de "Parrasio, Polignoto, Apeles, Ceuxis y Timantes... acompañados de los del devoto Rafael de Urbino y de los del divino Micael Ángel." Si, ciertamente, una música arrobadora suena en la lonja, tal música no era sino la que "diversos géneros de pájaros en riquísimas jaulas estaban haciendo [con] una confusa pero agradable armonía"; vocablo, este de armonía, que Cervantes emplea lás más veces que tiene que referirse al canto "no aprendido" de las avecicas.II Respecto a las grandes figuras de la pintura española, precisa que se diga que, si un Dominico Greco es el coetáneo de un Victoria, los nombres que enaltecen a la historia de este arte en la patria de Cervantes vienen después que los musicales; III pero Cervantes, que estuvo en Italia en la flor de su juventud y que, en cinco años, conoció las grandes ciudades italianas como Génova, Luca, Florencia, Roma, Nápoles, Palermo, Mesina, Ancona, Venecia, Ferrara, Parma, Plasencia y Milán, no dice haberse asomado -en el esplendor del Renacimiento y a las puertas del período Barroco- a los lugares donde la música, la pintura y la arquitectura se reunían para hacer de Italia el incomparable paraíso de las artes plásticas y líricas, ${ }^{1}$ sin dejar de saber que "los edificios reales, los alcázares soberbios, los templos magníficos y las pinturas valientes -son propias y verdaderas señales de la magnanimidad y riqueza de los príncipes"..v Verdad es que cuando se retrata a sí mismo en el prólogo a las Novelas ejemplares se olvida de esos ános, para no recordar sino su vida de soldado y los cinco años y medio de su cautiverio. El recuerdo de Roma, sin embargo, acude a su pluma en alguna ocasión; v no al recordar sus fastos, sino frente a la pobre aldea del Toboso: así en el capítulo virn de la segunda parte de Don Quijote. Buonarroti murió diecisiete años después de haber nacido Cervantes y sólo cuatro antes de su llegada a Roma, con lo que su memoria había de estar, por lo menos, tan fresca como su pintura, que, desplegada en la capilla del Papa Sixto, en el Vaticano, no pudo por menos de ver Cervantes. Admiración muda, en todo caso, cabe decir, si la hubo. Y en cuanto al Sanzio, que había decorado también sus loggie (lonja, en Cervantes, debe de ser traducción de loggia), había sido enterrado años antes (o a lo menos lo está ahora) en "aquel famoso templo de la Rotunda" que Cervantes recuerda en el capítulo mencionado. Entre los músicos famosos del momento, había allí españoles tan señalados como Tó-

1 Don Quijote conocía la musica di tavola (musique de table, Tafelmusik) y la menciona en el cap. L de la primera parte de su historia: "¿Cuál será oír la música que en tanto que come suena, sin saber quién la canta y ni a dónde suena?" 
más Luis de Victoria, el abulense a quien los italianos pensaban "generato di sangue moro" por el calor de sus inspiraciones, llegado a Roma tres años antes que Cervantes; joven como él, pues que había nacido dos años más tarde que el alcalaíno. $\mathrm{Ni}$ de Victoria ni de ainguno de los músicos de su tiempo hace mención Cervantes, salvo de Espinel, su no muy buen amigo, más por la circunstancia de su poesía, en cuyo "raro estilo" tiene la prima, así como en la guitarra,vi instrumento tan favorecido por Cervantes. Pero no es el raro estilo lo que en este arte le sugestiona, pues que, de haberlo sido, no habría dejado de mencionar, siquiera fuese de pasada, y entre los ciento cuarenta y cinco poetas del Viaje del Parnaso y los noventa y siete del Canto de Calíope, en la Galatea, a don Luis Milán, el valenciano, que también era poeta, elogiado por Gil Polo, aunque no tan afortunado como músico, autor de los finos contrapuntos con que rodea romances muy bien conocidos de Cervantes, vu no menos que Enríquez de Valderrábano, cuya Silva de Sirenas (en la que se incluye uno de los romances viejos que don Quijote recita, "Ya cabalga Calaínos") se imprimió en Valladolid en 1547, el año mismo del nacimiento de Cervantes. Sin detenernos en este punto de los romances que el gran escritor menciona en sus escritos, cabe decir que el hacerlo no supone que los haya tomado en las colecciones, como el Romancero General, o el Cancionero General de Hernando del Castillo, o la Silva de Romances de Esteban de Nájera, aunque conozca alguna y la cite,viri sino, simplemente, que los romances en boca de sus personajes eran tan populares como el de don Roldán, que canta el labrador en la madrugada, afueras del Toboso.

El desdén que Cervantes siente por Milán no es un caso único, porque lo mismo le ocurre con el segundo de nuestros tratadistas conocidos en materia de vihuelas, que es Luys de Narbaez, o Luis de Narváez en la ortografía posterior, autor de Los seys libros del Delphin de musica // de cifras para tañer Vihuela, ${ }^{2}$ impreso en Valladolid en 1538, dos años después que el de Milán en Valencia. Narváez, que estuvo, mediando el siglo, al servicio de Felipe II, a quien acompañó en su primer gran viaje, conocía ya en su tratado el arte polifónico vocal de Josquin des Près, Nicolás Gombert y algún otro músico flamenco, de lo cual deja testimonio en las transcripciones que hace para vihuela de obras de aquéllos, mezclándolas con sus propias fantasias y diferencias, y su manera de tratar en ese instrumento villancicos

2 Se discute acerca de cuál sea el título correcto de la obra de Narváez. La portada y los títulos de los libros interiores dicen, en la mayor parte de los casos: Los seys libros del Delphín de música // de cifras para tañer vihuela, pero en su Prólogo el autor dice taxativamente que ha "trabajado de hazer estos seys libros de música de cifras para tañer Vihuela intitulados del Delphín". Ello induce al Sr. Pujol a creer que el título correcto ha de ser Los seys libros del Delphín (como se dica también en el colofón del impresor) y no Delphín de música, como corrientemente se cita. Pero Narváez añade a seguida: "Y con justa causa, porque es un pescado muy aficionado y sentido en la música del qual se escriben grandes cosas." Se refiere, claro está, a la fabulilla de Arión, que a lomos de un delfín, arribó 9 las costas de Grecia, y así se le ve, en efecto, en el dibujo que figura al frente del libro de Narváez. Lo curioso es que lo que interesa al vihuelista no sea Arión, con su vihuela o guitarra, sino la cabalgadura. Ese regusto renacentista se encuentra también en otros tratadistas de vihuela como Valderrábano en su Silva de Sirenas y Fuenllana en su Orphénica lyra. Pero parece que Narváez juega con el vocablo y que el delfín sca, en realidad, el príncipe don Felipe, delfín del Imperio, dicho a la manera francesa. Er la época de la publicación de su libro, Narváez estaba al servicio de don Francisco de los Cobos, secretario de Estado desde 1516 y más tarde del Consejo Supremo y del Consejo de los tres magnates. En 1547 fallece, y al año siguiente Narváez pasa al servicio del príncipe don Felipe, a quien acompaña, en su primer viaje al extranjero, por varias ciudades de Italia, Alemania y los Países Bajos, donde Narváez pasa el invierno de 1549 a 1550 con los demás cantores de la capilla, de los cuales era maestro. 
y romances. Narváez, además, fué poeta discreto, como puede observarse en las "coplas" que inserta en su libro y que son de su propio numen. Menéndez Pelayo le coloca en un alto puesto como poeta en su Historia de las ideas estéticas en España, llamándolo "felicísimo poeta a lo divino y humano" que "templaba en alto tono su lira", como Calíope o el pastor Lenio, sin que Cervantes se dignase escuchar mejor los acordados cantos del vihuelista de Castilla que los del valenciano.

No es aventurado suponer que Cervantes, no sabemos cómo ni cuándo, debió de presenciar alguna de las grandes fiestas cortesanas en las cuales alcanzaba el arte teatral ese boato, tan característico del período barroco, que maravillaba a las gentes con el uso de máquinas, tramoyas o ingegni, todavía desusadas o muy rudimentarias en España en la juventud de Cervantes, pero no sin tradición, porque había una zona religioso-popular que desde largo tiempo atrás copiaba en España modelos que le llegaban de las naciones vecinas, especialmente de Italia, en los espectáculos callejeros que fueron conocidos de Cervantes en las fiestas del Corpus: muy famosa una de ellas, la del año 1593, en la ciudad de Sevilla, que Cervantes presenció, sin duda, y entre cuyos diversos atractivos hubo el de danzarse la zarabanda (por más que estuviese prohibido cantar su copla, so pena de seis años de galeras, desde diez años antes, $\mathbf{x}$ aunque Cervantes la tenía por un són "nuevo entonces en España") . $\mathbf{x}$

Tan rápida emulación despertó el arte de la escenografía, ya en gran predicamento por los años en que Cervantes estuvo en Italia, que todavía en vida suya un coetáneo como Agustín de Rojas menciona en el Viaje entretenido, redactado en 1602, el nombre del que quizá sea el primer tramoyista español conocido, o a lo menos de los primeros, "Juan Díaz, maestro de hacer nubes en los tablados"; esas nubes, dice Cervantes en el prólogo a sus Comedias, impresas en 1615, que "bajaban del cielo con ángeles y almas".xr Y no en las pobres representaciones de Lope de Rueda, con quien Cervantes coincidió en Sevilla en 1564, sino en algunas que él había visto en los intermezzi, en uso en Italia desde mucho antes de la estancia de Cervantes, en el último tercio del siglo xvi, y de cuya magnificencia hay testimonios gráficos en grabados un poco posteriores: así, por ejemplo, los dioses que bajan de los cielos en el intermezzo de Rinuccini y Lucas Marenzio representado en Florencia en 1589.xi Las referencias escritas sobre tales apariciones son, sin embargo, muy anteriores. En términos generales, los progresos en la escena italiana van desde 1452 a un siglo más tarde. En la primera de estas fechas, Leon Battista Alberti dibujó un teatro para el papa Nicolás V. En una representación del Amphitruo, de Plauto, en 1487, aparecía ese "paradiso con stelle et altre rote" que tanto se mencionan antes y después. Hay muchas descripciones relativas a la puesta en escena en el Tratado de arquitectura, de Vitrubio, y en Antonio de San Gallo, el joven (1485-1546); pero todas esas teorías cristalizan en la Architettura de Serlio, en 1551, donde ya se ve a la orquesta en la platea, delante del escenario.xir Fiestas de un porte semejante no eran desconocidas en España, y Moratín recuerda las que se hicieron en 1548 en Valladolid para celebrar el casamiento de la infanta doña María, hija del Emperador Carlos V (que no vió la representación) con el Archiduque Maximiliano, "comedia, dice, xrv adornada con suntuoso aparato y decoraciones a imitación de las que entonces se hacían en Roma". En Roma y en otros muchos lugares de Italia, que envió 
también la letra para la comedia, debida al numen de Ludovico Ariosto, algunas de cuyas estancias sabía cantar don Quijote, según él mismo nos lo dice en el cap. LxII de la segunda parte de su historia.

Importa señalarlo, porque es éste el tiempo en que se extienden por España los gustos italianos en la poesía y en el teatro, que Cervantes acusa en obras suyas, desde la Galatea (parte I, 1585) al Persiles de sus últimos años, aparecido en la imprenta al año siguiente de su muerte, e, igualmente, en las comedias tituladas La casa de los celos y El laberinto de Amor. Aunque impresas éstas un año antes de morir Cervantes, revelarían, por el solo hecho de su italianismo renacentista, una confeccion anterior. Las tramoyas habían progresado considerablemente en España durante esos años, y cuando Cervantes manda a la imprenta en 1615 sus Ocho comedias y ocho entremeses reconoce al toledano Pedro Navarro por el primero que "levantó y adorno" las comedias, "inventó tramoyas, nubes, truenos"... "pero -añade- no llegó al sublime punto en que están ahora". ${ }^{3}$ Sublimidad sin duda modesta; y en cuanto a la invención, claro se ve en esas líneas de Cervantes, y en las de Rojas cuando dice que Navarro "fué el primero que inventó teatros", que inventar tenía entonces un significado tan humilde como la sublimidad que Cervantes adjudica a lo que se veía ya, en el tercer lustro del siglo xvir, en las escenas españolas: no sin disgusto para Lope de Vega, que encontraba en el exceso creciente de las tramoyas un peligro para el interés del público, pues que, de la comedia, se desviaba a la fantasmagoría e ilusión de los ojos, no del sentimiento.

Pero este hecho, el de la creciente riqueza ornamental en el decorado escénico, es fundamental en el proceso estilístico que lleva desde el Renacimiento, con sus intermezzi al modo del Orfeo de Poliziano (Mantua, 1471 y 1483, fechas probables), a los teatros, como el del Palladio (1580-1584), con sus decorados permanentes en trompe l'oeil, hasta las fiestas fastuosas en la corte francesa, la más famosa de las cuales es el Balet Comique de la Royne, representado el 15 de octubre de 1581, y que queda minuciosamente descrito por su principal organizador, Baltasar de Beaujoyeulx, en un libro, con grabados y música, mandado hacer por el rey Enrique III, promotor del espectáculo, para que sirviera de ejemplo en las cortes europeas.xv Y pronto sirvió en Inglaterra, y, en España, en cuanto Isabel de Borbón, la hija de Enrique IV y de María de Médicis, casada hacía varios años con el príncipe Felipe, hijo del tercero de su nombre, quiere, al abandonar la corte los lutos por la muerte del rey, conmemorar el cumpleaños del joven monarca, que en 1622 alcanzaba los diecisiete de su edad y uno de reinado, con una fiesta muy directamente inspirada en aquella francesa y otras posteriores del tiempo de Enrique IV, y para la cual el Conde de Villamediana redacta un argumento titulado La gloria de Niquea. Una descripción al pormenor, a más de la que el propio autor da en su edición,xvi quedó redactada por don Antonio Hurtado de Mendoza, si bien ninguno de los dos nos dice con claridad quiénes fueron los autores de la música, al parecer de los

3 Alberto Nazeri de Ganassa y su compañía de trufaldines dieron representaciones en Madrid en el año 1574. En 1579 se inauguró el teatro de la Cruz y en 1582 el del Príncipe, donde las funciones habrían de ser un poco mejores, escénicamente, que en las compañías trashumantes. Los primeros ensuyos teatrales de Cervantes vienen por esta época, pocos años antes de 1585, cuando, al irse a Sevilla, dice que dejó "las plumas y las comedias". 
españoles más notables del tiempo: un "maestro de la Real Capilla" no mencionado, y sí aludidos Juan Blas de Castro (a quien tanto admiraba Lope), Ályaro de los Ríos y un Palomares (de los dos, Pedro y Juan, que se conocen); xvir la fama ya antigua de los cuales, o por lo menos de alguno de ellos, no habría dejado de sonar en los oídos de Cervantes.

Entre los muchos aspectos que señalan en las artes plásticas el camino que lleva desde el Renacimiento al Barroco, el de la suntuosidad escénica es sintomático, porque todo el Barroco se desarrolla dentro de ese sentido, teatral y suntuario. Miguel de Cervantes es uno de los testigos de mayor excepción en dicho proceso del aparato teatral, extraordinariamente rico en Italia; y muy pobre, salvo lo que ocurría en la corte, dentro de España; pobreza que resultó en favor suyo, porque al no disiparse su espíritu en orgías visuales, buscaba la concentración en el carácter y en el tono expresivo; pero que no fué solamente pobreza castellana, porque ni los interludes ingleses ni las piezas francesas del Théâtre de la Foire se movían en escenas más ricas que las españolas.

Ocurre así que Cervantes sea uno de esos artistas que viven y crean en la zona fronteriza entre dos grandes etapas de la historia de los estilos. Cervantes es un hombre del Renacimiento en la Galatea. En Don Quijote es, sin que corramos mucho riesgo al creerlo, un hombre del Barroco, y la figura del Caballero es, en España, la más admirable figura simbólica de ese movimiento que conduce a la Contrarreforma y a una necesidad de expansión que tiene a América por el testimonio más elocuente. Una hijuela del Barroco - por reacción contra sus excesos y en las zonas inferiores de la sociedad coetánea- consiste en el realismo que tiene tan cumplida manifestación en las Novelas ejemplares y en los Entremeses cervantinos. El contraste entre sus obras pastoriles y estas otras, que existe constantemente en Don Quijote, no es, por otra parte, un rasgo original del gran escritor, sino propio de la época, como lo certifican los playlets del tiempo isabelino, ${ }^{4}$ los caracteres rústicos en Shakespeare y las piezas burlescas del teatro francés de la Feria. Es un tipo de reacción del espíritu del pueblo. De él estuvo lleno el teatro religioso-popular de la Edad Media. Ese espíritu faceto trajo consecuencias fecundas, llegando en España al sainete y géneros similares que reaccionan en el siglo xviri contra el neoclasicismo pastoril, ahora de influencia francesa: la comparación entre ambos tipos de bucolismo, el italiano renacentista en el xvi y este otro, dentro de España, puede dar lugar a puntos de vista interesantes. Cervantes se aprovecha frecuentemente del juego de los contrastes: las figuras de don Quijote y de Sancho Panza son su encarnación viva; y aun dentro de uno de los personajes de la "historia", el contraste se observa entre el nombre irónicamente idealizado de Dulcinea y su apellido tan crasamente vulgar, al ras del suelo del Toboso. Por fin, y como cerrando armoniosamente el ciclo de sus

4 El primer anuncio callejero o playbill de espectáculos que se conoce de Inglaterra se conserva en la Biblioteca de la Universidad de Harvard y data de 1660 . Anuncia varias diversiones en la Feria de San Bartolomé (recuérdense los teatros de la Foire en París). Además de danzantes en la cuerda floja, hly funciones por títeres "grandes como niños de dos años"; personajes clásicos como "their Man Miles", y otros de la comedieta italiana como Punchinello, el abuelo del famoso Punch inglés. Pero es interesante subrayar que entre las atracciones que se ofrecen figura la de "the brazen speaking Head", que don Quijote escuchó en casa de don Antonio Moreno (Wriliam Van Lennep, The Earliest Known English Playbill, en HLBul, Autumn, 1947). 
creaciones, Cervantes vuelve la mirada, en el Persiles, a los imaginarios paisajes por donde se extendió la fantasía de sus personajes, y a los viejos romans caballerescos. Acá y allá resuenan instrumentos, aparecen las danzas: muy distintos, unos y otras, según que la obra pertenezca al período renacentista y su bucolismo, o al realismo barroco de su teatro y novela breves. Para tener idea de su significación, aunque sea de una manera sumaria, conviene recordar, por brevemente que se haga, el estado de la música en España en la segunda mitad del siglo en que Cervantes vivió.

La vida del gran escritor transcurre desde los últimos años del Imperio a los de la infancia del biznieto de Carlos I, el cuarto Felipe. Cervantes nació en la universitaria villa de Alcalá, junto a los henares del Jarama, en 1547, y el Emperador se retiró a Yuste casi diez años después, en 1556. Allí vivió, hasta 1558, rodeado de sus cantores y de sus ministriles: aquéllos principalmente flamencos; estos otros, españoles. Su hijo Felipe, segundo de su nombre, reina más de cuarenta años, desde el retiro del Emperador hasta 1598, en que Felipe muere, por los años malaventurados en que Cervantes conoce las cárceles sevillanas. Casi toda la vida de Cervantes se consume en sus actividades guerreras, sus viajes, las inquietudes que le causa su impecunia y sus pequeños oficios durante el reino del monarca que mandó elevar el imponente monasterio de El Escorial y que desdeñó la imaginativa pintura del Greco: contraste de sentimientos que es interesante subrayar. Tras de su vida agitada por el litoral mediterráneo, más llena de penalidades que de satisfacciones, Cervantes, al regresar a España una vez rescatado de su cautiverio, prueba su arte en las letras; y lo que su musa le inspira no es aún la narración de sus desventuras, sino la sonrisa de sus experiencias en la literatura renacentista. La primera parte de la Galatea, en efecto, llega con los cuarenta años de Cervantes, en pleno reinado de Felipe II. El año de 1604 es el del "privilegio" para Don Quijote. Al siguiente, nace Felipe IV: Cervantes conoce ahora las cárceles de la corte, en Valladolid; pero Don Quijote aparece a la luz de los siglos en la imprenta madrileña.

La música alcanza en España durante el Imperio un estado de florecimiento que heredaba desde la generación anterior, cuando el hermoso Felipe llega a España con su consorte la princesa Juana, hija de los Reyes Católicos. Poesía y música adornaban la corte de don Juan II, el padre de la reina Isabel y de su hermano, tantas veces vilipendiado, Enrique IV de Trastamara, buen cantor y tañedor de laúd. Esa música, que en su mayor parte era poesía cantada ( $\mathrm{y}$ a veces poesía cantada y bailada), tenía en España una solera de siglos, en cuyo poso habían intervenido caracteres autóctonos constantemente envueltos en influencias - digamos modas o modos de arte- que habían llegado a las cortes castellanas unas veces por el norte, con la poesía y la música trovadoresca, otras veces por el sur, con sones de laúdes y rabeles moriscos y, acaso, con su modo peculiar de poesía; sin cantar el fuerte influjo de la música litúrgica de Roma, que desde antaño pugnaba por desterrar las costumbres religiosas de los españoles: el canto de sus primitivos ritos cristianos, al cual, por la convivencia de los naturales con sus invasores del norte o del sur, se entendió como canto de la liturgia visigótica o mozárabe.

De la afición que la reina Isabel sentía por la música es testimonio su rica 
colección de instrumentos y los libros de música que poseía. Dan fe de ello los minuciosos inventarios testamentales. Música religiosa y profana, en cuyas dos zonas habían comenzado a prosperar las artes de la polifonía, ya conocidas en su aspecto incipiente por el rey Alfonso el Sabio y que, en tiempos de los Reyes Católicos, florecían tras de haberse elevado a un rango de "Ars Nova". Tales novedades cobrarán fuerte impulso al llegar el Archiduque Felipe con sus capillas de cantores flamencos. España entra, con el siglo xvi, en su época de esplendor musical, y alcanza a todo lo largo de él su apogeo, para decaer en el siglo siguiente, cuando la música deja su cetro en España a la pintura. Catalina de Aragón y el príncipe don Juan, hijos de Isabel y Fernando, habían sido músicos muy señalados. Shakespeare habla de Catalina en su Enrique VIII, el rey barba azul, de quien ella había sido la primera esposa, y Juan del Encina recuerda en su Triunfo de Amor el repertorio instrumental que resonaba en la corte del príncipe castellano. Poeta y músico, Juan del Encina, como su colega y paisano Lucas Fernández, son figuras eminentes en los albores del teatro español, que pertenecía a un género fuertemente tradicional, pero muy semejante en ciertos aspectos al de otros países, sobre todo los latinos. Teatro, dígase en seguida, en el cual la música tenía una participación más importante que la que Cervantes conoció con los primeros "autores" y "representantes" que recuerda, y que no van más arriba de Lope de Rueda, que es de la generación siguiente a Encina, muerto aquél treinta y cinco años después que el salmantino. En las piezas de Encina, donde el aire elegante del Renacimiento italiano se mezcla con el rudamente castellano, resuenan las músicas polifónicas con que el arte del tiempo trataba el villancico vernáculo; y éste, como ocurría sobre todo en Italia en la misma época, de su primera condición monódica y popular se había transformado en un arte de rica confección. El siglo xvi conoce, con Francisco Salinas, Antonio de Cabezón y los grandes polifonistas de las escuelas sevillana y castellana, Morales, Guerrero y Tomás Luis de Victoria, las etapas más gloriosas de la música española. Es, además, el siglo que trae una gran revolución musical: la de la monodía acompañada. Los grandes músicos españoles de Felipe II habían viajado mucho, con el unas veces, otras porque iban a la corte de los virreyes españoles de Nápoles. Esos viajes suponen un intercambio fecundo en técnicas y estilos, y donde ello se refleja con mayor originalidad es en la música para instrumentos. El laúd, que don Quijote sabía tañer, era el instrumento universal en el Renacimiento. Unas veces se tañía a solo, con caracteres virtuosistas que ya conocían los tañedores árabes; otras veces colaboraba con los cantores, acomodando las voces de la polifonía - que era la técnica más avanzada de composición conocida en ese tiempo- de tal manera que se centrasen en las cuerdas del laúd, dejando en libertad a la melodía cantada, o doblando a la voz. Así se cantaron aquellos romances tradicionales en España y, mejor que no en el laúd, en el instrumento con que se le sustituía en España, que era una guitarra provista de dos cuerdas más de lo corriente en ella, pero que era lo normal en el laúd. La guitarra, así modificada, tomaba el nombre de vihuela. Este nombre no es, en el Renacimiento, el mismo con el que el Arcipreste de Hita, por ejemplo, había denominado a sus instrumentos de arco o péñola, sino que ahora, y en este arte particular tomado del laúd, es una simple adaptación del vocablo italiano viola; mas 
no tampoco la vieja viola tocada con arco (como las gigas y rabeles) ni con púa (o pénola, como el laúd morisco), sino con los dedos, y que en Italia se practicaba, tanto como en España, desde los comienzos del siglo xvi. El conde Baltasar Castiglione, al que tradujo Boscán, practicaba tal arte como buen cortesano, tanto en su país como en España, alrededor de los años en que Luis Milán daba a la imprenta de Valencia, se estima que con tipos italianos, su célebre libro de vihuela El Maestro, el primero que se haya conservado en España.xvin Primero, no porque Milán inventara su arte o su técnica, por personal que fuese su aportación, sino porque la aparición de libros impresos con la tablatura del laúd ocurre solamente en los primeros años del siglo xvi, en Italia. No tardaron en entrar en España y, como es natural, trajeron algo que pertenecía al laúd propiamente dicho, para encontrarse con el que se practicaba en la vihuela española o en la guitarra. El arte del laúd se practicaba también en Italia sobre la guitarra ${ }^{5}$ que, en esta época, se denominaba allí viola. Pero

5 Algún vihuelista, como Narváez, muestra en la portada de su libro el instrumento al que consagra su arte, y que no es sino una guitarra. Lo mismo hace Bermudo cuando exhibe en su Declaración de instrumentos (Osuna, 1549-1555) una vihuela de siete cuerdas. Es inoportuno sacar conclusiones respecto a forma, tamaño, etc., de la "vihuela española" porque no se trata de documentos fehacientes, sino de malos dibujos. Se ha dicho, también, que la vihuela no aparece citada por ningún autor extranjero, de lo que se deduce que no se tocaba fuera de España. Es un razonamiento ingenuo. Tampoco \&e tocaría, según eso, la trompa, la chirimía, el bajoncillo, porque, claro está, en cada país se les llama por sus nombres y no ha de llamárseles precisamente por el nombre español, como es el caso de la vihuela. La. vihuela-guitarra se tocaba tanto como en España en la Italia del Renacimiento, bajo el nombre de vivola-viola. El dibujo de Marcantonio Raimondi, según un modelo de Francesco Francia, que muestra al tañedor famoso Giovanni Philoteo (1466-1538), sienta jurisprudencia, porque es de mano hábil. Philoteo toca un instrumento de siete cuerdas y once trastes, uno más que la guitarra-vihuela española, lo que muestra que aquél era hasta más rico en posibilidades. El clavijero, distinto del que hoy conocemos, no debe producir confusiones. Las guitarras tuvieron en Europa durante esa época clavijeros diversos; frecuentemente, los mismos que terminaron por caracterizar a las violas de arco y que también poseían los del tipo cetra-cítola. Una guitarra semejante a la del Philoteo está reproducida con ese nombre y circunstancias por Mersenne, entrado el segundo tercio del siglo xvir.

Para un instrumento así, de siete cuerdas, escribía sus Fantasías, mediando el siglo xvi -por la Época de Milán-, Melchiore de Barberis (Barberijs, Barberio o Barbariis), famoso tañedor de laúd, natural de Padua. Entre 1546 y 1549 publicó en Venecia diez libros de piezas en tablatura. (Cf. Adolf KoczIrz, Die Fantasien des Melchiore de Barberis fuer die sicbensaitige Guitarre, en ZfMusik, 1921, v, págs. 11-17).

Hay, de todo ello, el testimonio valioso de un testigo presencial, Vicente Espinel, que entendía de esos asuntos. Marcos de Obregón, su alter ego, vive en Milán (relación tercera, descanso v), en 1580 y concurre a casa del magistrado don Antonio de Londoño (personaje real que aparece con su propio nombre en la Relación), donde se practica la música de cámara más refinada. En Milán se encuentra a Bernardo Clavijo del Castillo que, años después, (hacia 1588) fué organista y maestro en la corte española de Nápoles, con su hija doña Bernardina. Esta tocaba el arpa, el padre la tecla y con ellos se unía Lucas de Matos en la vihuela de siete órdenes, "imitándose los unos a los otros con gravísimos y no usados movimientos", que es lo mejor que Marcos-Vicente ha escuchado en su vida. En el jardín de la casa de Clavijo se escucha al licenciado Gaspar de Torres, que canta acompañándose a la vihuela "con gallardísimos pasajes de voz y garganta", y en la sala del músico se entablan discusiones técnicas como es la del género enarmónico, que resucitó "aquel príncipe de la música, el abad Salinas". Los razonamientos por parte de Espinel son tan juiciosos que parece que estuviese hablando de los madrigales del napolitano Gesualdo, principe de Venosa, que era de ese tiempo. En casa del magistrado Londoño se celebraban reuniones semejantes a las que en Florencia, también por entonces, congregaba el conde Giovanni Bardi. En aquélla "tañíanse vihuelas de arco, con grande destreza, tecla, arpa, vihuela de mano, por excelentísimos hombres en todos los instrumentos".

Sería interesante examinar el libro de Philoreo titulado Il Viridario (Bolonia, 1513), donde habla de los más famosos tañedores de su época. Sobre Espinel, cf. el prólogo de Juan Pérez de Guzmán (1881) a la Vida del escudero Marcos de Obregón (Barcelona, 1910, ed. Biblioteca de Arte y Letras). Sobre el maestro Clavijo, cf. el folleto de Amalio Huarte y Echenique, Datos para la biografía de Bernardo Clavijo, Salamanca, 1917. En los documentos que publica no se le llama nunca "del Castillo". sino simplemente Bernardo Clavijo. 
viola y vihuela son dos diversas designaciones de una misma cosa. El libro de Milán se titulará en España como de vihuela, que es vocablo allí tradicional, añadiéndose do mano para no confundirla con las vihuelas de arco. En el se junta, sin mezclarse, lo importado con lo vernáculo; lo virtuosístico con lo polifónico y con lo que tendía a ser puro acompañamiento: un arte de transición, pues, visto en su conjunto, que no tardaría en elegir su camino por el lado de la monodía acompanada, cuando no quería mostrarse como hábil lucimiento del solista. (Todavía en Cerone, El Melopeo, Nápoles, 1613, "vihuela de brazo o violeta".)

Cervantes tuvo que saber algo de este arte del laúd y de la vihuela, porque son instrumentos que menciona en Don Quijote, de tal manera que deja ver su cualidad intercambiable, y pues que le sirven para acompañar los romances que dice. Poco después del auge de los vihuelistas, al finalizar ya el siglo, aquella manera de reducir las voces de la polifonía a una especie de simplificación consistente en dar "de golpe" las notas coincidentes en sus cuerdas (en "acordes") es causa de una revolución, antes aludida, de profundo sentido musical, porque terminará por desterrar las prácticas polifónicas, sustituyéndolas con lo que vendrá a ser una melodía solista, con acompañamiento armónico. Semejante acompañamiento irá reduciéndose a fórmulas cada vez más simples que se practicarán preferentemente en la guitarra.xx No ya en la vieja guitarra de cuatro cuerdas que con tanto primor y denuedo tañían preferentemente los barberos y los farsantes, sino en una de cinco, transacción entre aquélla y la vihuela de seis cuerdas; y este compromiso, si resultó favorable para la difusión de la guitarra, desde ese momento denominada "guitarra española", fué fatal para la vihuela polifónica, que desapareció a la par que el arte que le fué característico.

La guitarra de cinco cuerdas, de la que ya habla Bermudo en su tratado, con más o menos diferencias en la afinación respecto de la que se popularizó en tiempos de Vicente Espinel, se extiende por Europa, especialmente con los poetas de la Pléyade, Ronsard y sus colegas, para adquirir nuevo auge con Luis XIII, discípulo del español Brizeño, y con Luis XIV y su corte, y de allí cn adelante en los años románticos de $\mathrm{Pa}$ ganini, Berlioz, Gounod, hasta Massenet mismo.xx Lo más probable es que la guitarra que tocaban los pobres músicos de los primeros "pasos" y "entremeses" que Cervantes fué conociendo desde su infancia, desde los de Lope de Rueda, fuese la de cuatro cuerdas; pero los comediantes italianos de la Commedia dell arte tañían ya la de cinco, según es fácil comprobarlo. Conviene tener en cuenta que, cuando Cervantes, reiteradamente, habla de los "músicos" de estas incipientes comedias, hay muchos casos en los cuales solamente se trata de cantores que no tenían instrumentos de ninguna clase, cosa que también ocurría en Francia en ese mismo momento. Los músicos de los pasos de Lope de Rueda carecían incluso de una mala guitarra y cantaban sus romances a palo seco. ${ }^{6}$ Cervantes lo dice así en el prólogo a sus Comedias $y$ Entremeses: "detrás (de la manta vieja "que hacían lo que llaman vestuario") estaban los músicos, cantando sin guitarra algún romance antiguo”. Sin duda, alguna

6 "En Valladolid desenvolvió ampliamente Lope de Rueda su actividad: preparó carros y danzas, música de vihuela, compuso y desempeñó autos y echó los cimientos del primer corral de comedias" (Narciso Alonso Cortés, El teatro en Valladolid, 1551-1559, en BAE, vol. iv, pág. 611). 
de aquellas famélicas compañías de farsantes sería un poco mejor que las demás, y las que Agustín de Rojas menciona en su Viaje entretenido tenían por lo menos una guitarra ya:

Tañían una guitarra

y ésta nunca salía afuera

sino adentro, y en los bancos,

muy mal templada y sin cuerdas.

Pedro Navarro, el toledano, que sucedió a Rueda, se atrevió a presentar en escena a sus músicos: "sacó la música, dice Cervantes, que antes cantaba detrás de la manta, al teatro público". Esto ocurrió hacia 1570 , y quizá la guitarra sin cuerdas (lo que habrá que entender por 'de muy pocas cuerdas', suprimidas acaso las que doblaban o requintaban a las principales) de Rojas mejoró de condición y tuvo ya las cinco de rigor en la "guitarra española", con su técnica de ràsgueo ("a lo rasgado", dice Cervantes en Don Quijote), cuyo primer tratadista conocido es el catalán Juan Carlos (Amat) a fines del siglo, en 1596. Esa es la guitarra que aparecerá en seguida en manos de los comediantes italianos antes aludidos, según lo confirman los grabados de la época. Pero creer, como se ha dicho, que la guitarra fué un instrumento exclusivamente popular y que la vihuela era un instrumento cortesano es un poco exagerado. ${ }^{7}$ Sin ir más lejos, vemos a la guitarra con su nombre (guiterre, guitterre) en las elegantes manos de Ronsard y sus amigos, en pleno Renacimiento francés. Ya hemos hecho mención de Luis XIII. Madame de Motteville y Voltaire mismo han dejado constancia de cómo Luis XIV se salía de los consejos de ministros, tan aburridos, para irse a su gabinete con su maestro de guitarra. Las guitareries abundaban también en tiempos de la Regencia. Muy pocos años después del tratadito de Amat ya hay en Italia (1606) una simplificación todavía mayor de su sistema de cifrado (que procedía del laúd y vihuela); Montesardo propone sustituir los acordes por letras, Nova inventione d'intavolatura per sonare i balletti sopra la chitarra spagnuola senza numeri o note, lo cual, si reduce a un mínimo las combinaciones del enlace de los acordes entre sí, lleva a un punto máximo la facilidad de acompañamiento de los acordes rasgueados de arriba abajo o de abajo arriba. Nótese que ya se trata solamente de puros acompañamientos: de danza, en este caso, de canciones en otros, pero lejos ya de toda idea polifónica; simplemente armónica ahora, y, ésta, la más sucinta (o ramplona).

Remigio Romano, en sus colecciones o raccolte de "bellissime Canzonette musicali" publicadas en Vicenza, Venecia, desde 1618 a 1625, aplica el "abecedario italiano", a la "chitarra alla spagnuola". Otro autor, Giovanni Ambrosio Colonna, imprime en Milán, en 1620, un tratado de Intavolatura di chitarra alla spagnuola xxx y Giuseppe o Gioseppe Giamberti imprime en Roma en 1623 otra colección de Poesie diverse poste in musica. La boga de la guitarra española con el método sinté-

7 En la relación del proceso que se siguió en Puebla de los Angeles, México, a partir de 1554, con motivo del atentado que ocurrió allí contra el poeta de Cetina, encontramos: "tomemos una vihuela, ques temprano para acostar, y sentémonos a la puerta para tañer un rato..." (pág. 57); "pidieron a vn negro vna vihuela y este testigo tañó en ella..." (pág. 63).

En Francisco Rodríguez Marín, Nuevos datós biográficos de algunos escritores de los siglos xvi y xvii, en BAE, vol. v, 1919. 
tico de cifrado inventado en Italia es natural, porque significa el deseo de abandonar la "viola" polifónica, o sea la "vihuela" española, por los acompañamientos esqueléticos propicios a la monodía acompañada, la gran novedad del siglo. Pero si el acómpañamiento así realizado era el más propicio para las canciones y danzas entre las gentes menos exigentes en sus gustos, está claro que empobrecía notoriamente el tejido armónico que, con el alfabeto italiano, se reducía a un enlace sumario de acordes rasgueados hacia arriba o hacia abajo, según ha perdurado en la canción popular española, principalmente andaluza, acompañada a la guitarra; así se sigue haciendo allí y así se hace en los países hispanoamericanos.

Por muy "facilíssimos" que sean los tratados de guitarra que se imprimen en España en el siglo xvir, tienen pretensiones un poco más altas, y por ello mezclan la manera antigua de tablatura de Amat con el sistema alfabético italiano. El Método muy facilíssimo para aprender a tañer la guitarra a lo Español, impreso en París en 1627 por Luis de Briçeño,xxir enseña los sones por punteado y rasgueado. Briçeño, al que por errata de imprenta se le llama Briçñeo, todavía se verá apodado como Brecneo, para mayor variedad. Su libro está dedicado a Madama de Chales, es decir, que estaba en buenas manos y, con lógica, llama "aquerdos" a los acordes, que enseña a conocer "por una horden agradable y facilissima". Esta "horden" no es sino el procedimiento empleado por Amat, que derivaba de la pura práctica de los guitarristas populares, conforme a la cual los acordes van enlazándose unos con otros sucesivamente, según cierto movimiento de los dedos. De este modo, la posición de los acordes varía en cada uno de ellos, evitando los enlaces en posición directa. Las notas de cada acorde, que todavía no tienen función bien establecida, aparecen donde buenamente caen, así como sus duplicaciones, y Amat tiene que advertir al aprendiz en qué cuerda está el baxete o el alto o el tiple. Pietro Millioni inventa en 1638 nuevos modos de accordatura, o sea, de templado, lo cual dará diversas posiciones de los acordes, que mejoran su encadenamiento en su Corona... d'intavolatura di Chitarra Spagnola. Un portugués, Doizi de Velasco, imprime en Nápoles, 1645, un Nuevo modo de cifra para tañer la guitarra con variedad y perfección $\mathrm{y}$, por fin, en 1674 aparece en Zaragoza el método de Gaspar Sanz, Instrucción de música sobre la guitarra española. El tratado de Millione, entre tanto, seguía muy practicado en Italia, y en 1673 Lodovico Monte lo reimprime en Venecia, con "un altro alfabetto et accordatura straordinaria", y con algo más notable aún, que consiste en la manera de acordar seis guitarras para poder tocarlas "insieme in concerto, ciascuna per differente chiave". También Sanz siente necesidad de reimprimir su tratado, que había dedicado al segundo don Juan de Austria, sin consecuencias notables, al parecer, ya que en 1697 toma las planchas, que había grabado y fechado él mismo y, con algunas añadiduras lo dedica "a la Magestad Católica del Rey Nuestro Señor Don Carlos Segundo, monarca de las Españas y del Nuevo Mundo".xxir El siglo xvir termina así, por lo que a la guitarra española se refiere. En el xvin todavía sigue empleándose el sistema alfabético que Sanz había utilizado moderadamente, combinándolo con la tablatura tradicional, en una técnica que en principio se basa en la de Amat. Unas veces en punteado y otras en rasgueado aparecen allí en su gran variedad la mayor parte de las danzas españolas de ese siglo que vemos mencionadas en las obras de 
Cervantes y en las de sus sucesores para el teatro; pero el influjo italiano es grande en Sanz, como el francés lo había sido en Briçeño; en aquél, por lo que se refiere a multitud de detalles técnicos, en ambos por la desfiguración de los aires de nuestras danzas populares como la zarabanda, la chacona y las folías que eran en Cervantes tan movidas y sensuales y que en esos músicos son ceremoniosas, acompasadas y cortesanas, con lo que su primitivo carácter se ha evaporado.xxiv De cualquier modo esas obras y las demás citadas sirven para comprobar que la guitarra amenizaba la mejor sociedad tanto en el siglo xvi como en el xvir, y en España como en sus dos hermanas latinas.

Puede añadirse un detalle sustancioso, y es que cuando Mazarino lleva a París la primera ópera italiana que se escucha en la corte francesa, el Orfeo de Luigi Rossi, en el año 1647, el dios tracio aparece en escena tocando buenamente una guitarra (que en el grabado de Torelli parece tener solamente cuatro cuerdas).xxv Por lo que se refiere a la "vihuela", se la encuentra en manos populares en toda la literatura castellana del siglo xvi; pero en la mayor parte de los casos se advierte que, cuando no es la vihuela de arco, es simplemente una guitarra. El nombre no es lo que hace a la cosa. Lo que diferencia en el siglo xvi a la vihuela de los vihuelistas respecto de la de las gentes vulgares, ${ }^{8}$ así como de la guitarra, no es el hecho de que una tenga dos cuerdas más que la otra, sino el diferente arte que se practicaba en ellas y que, en los vihuelistas, era un rico arte trasplantado en gran parte del laúd flamenco e italiano, mientras que en la vihuela y la guitarra populares, que eran la misma cosa, su colaboración polifónica con la voz era mucho más rudimentaria: esta simplicidad es la que lleva, precisamente en la guitarra, a la revolución monódica, con su tendencia al acompañamiento en acordes rítmicos; trascendental revolución que se ha supuesto que llevaron a cabo los operistas florentinos de la camerata del Conde dei Bardi, pero que tenía esos orígenes en todos los países donde se practicaba el acompañamiento de la canción, ya al laúd, ya en la vihuela, ya —en último y más reducido extremo - en la guitarra. La primitiva de cuatro cuerdas era demasiado pobre; la violavihuela ítalo-española de seis cuerdas era todavía demasiado rica, como el propio laúd. Por eso, en cuanto se llegó en España al compromiso entre ambas, que es la guitarra española de cinco cuerdas, la invención fué acogida con júbilo en el país de la monodia accompagnata. La polifonía pasaba a mejor vida, y estaba pasando ya en tiempos de Cervantes. Poco afecto a las prácticas eclesiásticas, no debió él de escuchar mayormente las obras de los grandes polifonistas italianos o españoles, al paso que ese otro arte de arranque popular, cantante y danzante, era lo que le llegaba al alma. Ahora sí que va a poder hablarse propiamente de "armonía" y de "acordes". en lugar de fugas y contrapuntos "que se suelen quebrar de sotiles".

La guitarra única de los primeros representantes se convierte en dos en los Entremeses cervantinos: es un progreso, pero la sustitución de laúdes y vihuelas por

8 La idea, extendida después de Pedrell, de que la vihuela era un "instrumento cortesano" y la guitarra un "instrumento vulgar" se apoya, equivocadamente, en el hecho de que Bermudo hable de ந "vihuela cortesana". al referirse al arte de los vihuelistas; pero Bermudo habla también, repetidamente, de la "vihuela vulgar", que no era instrumento distinto, sino que se encontraba en otras manos, o bien era simplemente la guitarra, cuando no eran especialistas como Bermudo quienes hablaban. 
guitarras "a la española" no se hace repentinamente. Rojas hace acompañar en una vihuela las décimas (o espinelas), y el instrumental de los comediantes que reseña en el Viaje entretenido constaba, por lo menos, de dos instrumentos del mismo orden: un laúd y una vihuela en Rojas, que son el equivalente de las dos guitarras en los Entremeses cervantinos.

LA Música pastoril.-Apenas veinte años antes de la Galatea, la Diana de Jorge de Montemayor exhibe un repertorio de músicas pastoriles cuyas combinaciones instrumentales y vocales muestran un sentido musical fino e inventivo. Cervantes se limita a mencionar o poco más los instrumentos que han de servir para acompañar al canto, por lo regular a una sola voz, aunque a veces alternen dos o más, acompañadas por instrumentos. Más raro es encontrar (pág. 83 de la edición Bibl. Aut. Esp.) tocando a un grupo de cuatro rabeles en una delicada música especial que luego alterna con el canto.xxvi La mención de la pág. 91 puede estimarse como un trío simultáneo de canto, zampoña y rabel.xxvir El canto responde a versos en décimas, mientras que en otras ocasiones han sido sextinas, a solo o dúo (pág. 21), sonetos, estancias (octavas reales), silvas y villancicos; esta vez el villancico es monódico, sin acompañamiento, caso que se presenta frecuentemente, así como la simple recitación hablada. El canto alternado en dos instrumentos no es raro (pág. 24) y aun a veces se acompaña con tres instrumentos, dos de los cuales son zampoñas y el otro un rabel.xxvir Quizá el caso de polifonía más nutrida en la Galatea y, en general, en Cervantes, sea el de un villancico a seis voces, donde se alterna, sin duda, la copla a solo y el estribillo en las voces restantes: "todos seis entonaron sus voces, y comenzando el uno y respondiendo todos y con muchos placenteros alaridos dieron principio a un gracioso villancico" (que, por lo demás, podía ser monódico).

Junto a los instrumentos mencionados, tópicos en la poesía pastoril, imitación directa de la Aminta y de otros modelos italianos, aparece el arpa, tañida por un ermitaño que se acompaña sus versos en silva, utilizada, en otros casos, para acompañar sonetos (págs. 186, 247 y 594) xxix Una vez (pág. 31) es un laúd el que acompaña al canto en octavas. La flauta acompaña a un soneto, alternativamente con una zampoña (págs. 77 y 92). En ocasiones pueden unirse gran número de instrumentos de la misma clase, pero no se dice cuántos: "al són de muchas zampoñas y acordados caramillos" (pág. 32). "Triste y agradable música de varios rabeles” (pág. 83). Otras veces se trata de la garrulería de los pajarillos. Cervantes entiende en este caso, como antaño Berceo, y Juan de Mena, que los pajarillos hacen una "suave armonía" o "suave música y armonía", "dulce armonía” y "concertado canto", que en el Persiles se entiende ya como conjunto de "voces", $x x x$ quizá como reminiscencia del vocabulario de los músicos polifónicos. Determinados instrumentos van acompañados de calificativos que indican sus particularidades, ya en la diminuta y fina apariencia de los rabeles, "polido rabel", "pequeño rabel", "que sonaba acordada y suavemente" (pág. 22), como en la lira, que es la "templada lira". Alguna vez, el cantor hace antes de cantar un pequeño preludio instrumental; así, la musa Calíope, en ese instrumento. Los tamborinos se unen a otrọs instrumentos para acompañar las danzas, y 
éstos son las flautas para las "madrugadas" (pág. 38) a los recién casados; la "regocijada gaita", el "acordado rabel", el "antiguo salterio", los "cursados albogues" (que como se verá en Don Quijote son las chapas o tejoletas) y las castañetas, adornadas con cintas. "Muchos pastoriles instrumentos" que, tañidos por sus personajes, daban una música no inferior a la que "suelen dar las acordadas músicas que en los reales palacios se acostumbran". Lira y zampoña "y los otros instrumentos" entonan una especie de preludio instrumental que sirve, como el antiguo silete eclesiástico, para hacer "prestar a los presentes un sosegado y maravilloso silencio", tras de lo cual el pastor Orompo recita sus desoladas octavas. Esta recitación puede hacerse con las églogas y aun con una canción misma (pág. 53), en la cual es flagrante y fragante la influencia de Garcilaso, que habría llamado asimismo "égloga" a la que las pastoras piden a Damón, rogándole que "nos digas la canción de Lauso".xxxi

La melancolía de una música "tristc y agradable", como la de los rabeles antes citados, está varias veces entonada por flautas en la comedia la Casa de los celos. Una vez (vol. II, pág. 186, ed. Colección Universal), mientras que un personaje duerme al tiempo en que aparece un espíritu; más tarde (pág. 225), es simplemente "música triste", y, se añade, "como la pasada". El Temor, la Sospecha, la Curiosidad y la Desesperación, después los Celos, desfilan preludiados por la misma música. En otro pasaje de esta comedia el pastor Corinto y un rústico dialogan, mencionando por su orden las cuatro voces del coro como "tiples, contralto, tenor" y "contrabajo es muy mejor".

Otro pastor, Lauso, aparece bajando de su montaña "con su guitarra", que no habíamos visto en estas manos antes de ahora. Importa notar que el "cantar"

\section{Corrido va el abad por el cañaveral}

(pág. 256) es lo que se entiende por un zéjel perfecto. Los versos de los tercetos son en consonantes, pero el verso de vuelta asonanta con los del estribillo. Otro zéjel se encuentra en los Baños de Argel (vol. III, pág. 86, ed. Colección Universal), no en boca de árabes, sino del cristiano Ambrosio:

Aunque pensáis que me alegro conmigo traigo el dolor.

El verso de vuelta es consonante con el segundo del estribillo, que se repite en cada vuelta. El cántico lamentoso de un pastor se llama canticio en la Casa de los celos, y el pastor Corinto hace eco a la pastora Clori, cuando canta el villancico:

$$
\begin{aligned}
& \text { Derramastes el agua la niña } \\
& \text { y no dijistes: "¡Agua va!”, }
\end{aligned}
$$

"trastocando" el villancico, es decir, contrahaciéndolo:

Cautivástesme el alma, la niña y tenéisla siempre allá...

No son muchas las menciones musicales que Cervantęs hạce en los Trabaios de Persi- 
les y Sigismunda y éstas pertenecen al género pastoril, como la "zampoña de Salicio". Los pastores tañen el tamboril y la flauta juntamente, en una manera de música que estuvo muy extendida por varios países de Europa en los siglos xIII y xIV, especialmente en la época trovadoresca, algunas de cuyas danzas, como las estampidas, han sido impresas en discos gramofónicos por Curt Sachs, para tamboril y óboe (chirimía) y piccolo o caramillo, semejantemente a lo que continúa haciéndose hoy en el País Vasco con los tañedores de chistu y tamboril. Es de notar que en las estampidas grabadas por Sachs se encuentra inequívoca la cadencia final del aurresku.xxxir

Los carros, indispensables en las fiestas ciudadanas del Renacimiento y en las procesiones del Corpus, hacen su aparición en el capítulo xvi del Persiles. Por su descripción, se trata de una de las figuras alegóricas típicas en los espectáculos cortesanos de Italia y en los ballets de la corte francesa, al paso que resonaba un "suavísimo són" formado por diversos instrumentos de música, que no se especifican (pág. 614 de la ed. Bibl. Aut. Esp.). En diferentes ocasiones es el arpa el instrumento elegido para acompañar a las canciones. En el Persiles se trata de un soneto (pág. 594); en la Galatea, de una silva. En la Ilustre fregona el soneto está acompañado por los músicos de oficio en un arpa y una vihuela, como serenata que dan a la hermosa Constanza, $\mathrm{y}$, cuando los músicos se retiran, ya a la madrugada, se despiden con una tocata de chirimías. Es interesante saber que en los templos como el que Cervantes menciona en el cap. $\mathrm{x}$ del Persiles, la música que se tocaba era vocal e instrumental conjuntamente y de altos vuelos: "hundíase el templo de música, así de voces como de instrumentos", cosa más propia del Barroco italiano que de la severa música "a cappella" de la polifonía religiosa española en la madurez de Cervantes, aunque, con instrumentos, pudo escucharla en su juventud xxxm en España también.

Las menciones relativas a la música que Cervantes hace en el Viaje del Parnaso pertenecen principalmente a las que quedan mencionadas en las obras de carácter pastoril. Mientras que hemos visto emplear a Cervantes el vocablo canticio, en sentido de canticum, aquí emplea el de cantilena, que es de riguroso abolengo latino y que, en el latín medieval, se empleaba en el sentido del són de una danza (cantilena de chorea), no muy frecuentemente antes de Cervantes, en quien "cantar con melodía" es cantar a una voz sola y entonadamente. Como todo sonríe en el Parnaso, la música triste que antes se halló en tambores y trompetas, incluso en flautas, ahora tiene un carácter enteramente distinto en las tocatas de clarines que estallan al llegar la real galera:

$$
\begin{aligned}
& \text { El són de los clarines la ribera } \\
& \text { llenaba de dulcísima armonía, } \\
& \text { y el de la chusma alegre y placentera. }
\end{aligned}
$$

Cervantes se acordaba ahí de la algarabía que solía recibir a las naves cuando desembarcaban en los puertos mahometanos, como se lee en los Baños de Argel: "suenan chirimías y grita de desembarcar".xxxrv

El "arpa de David" acompaña en el Parnaso "sacros himnos", según es la ley. pero es notable encontrar en el mismo sitio un motete monódico:

Un motete imagino que cantaba con vor. siiave; yo quedé admirado... 
y quien lo canta es Jerónimo de Castro, a la sombra de un mirto, cerca de Alonso de Ledesma, que "al pie sentado de una antigua encina" estaba componiendo "una canción angélica y divina". No menos famoso era ya entonces Espinel, ${ }^{9}$ tan notorio músico, "aunque tiene parte de Zoilo", como tantos, y que ha dejado mención de sus notabilidades contemporáneas en el Escudero Marcos de Obregón. Cervantes recoge la invención, tópica desde entonces, de la añadidura por parte del inventor de las espinelas de una quinta cuerda de la guitarra, que Cervantes, siguiendo una idea muy repetida luego, pensaba ser la primera: "en la guitarra tiene la prima", dice. No conviene entender esta afirmación, extendida a su "raro estilo", demasiado literalmente. Lope, más cauto, sólo dice en la Dorotea que Espinel añadió otra cuerda a las cuatro de la guitarra.xxxv No es muy seguro esto, porque ya se ha dicho que el P. Juan Bermudo habla de guitarras con cinco cuerdas, pero Espinel pudo hacer de uso general y popular lo que en Bermudo era todavía relativamente raro, y, en buena parte, especulativo. La afinación de la guitarra a mediados del siglo xvi consistía en las notas dofa-la-re, que, en la vihuela se enriquecía con un sol por abajo y otro por arriba, o sea sol-do-fa-la-re-sol. Así dice Bermudo que "si la guitarra queréis hacer vihuela ponedle una sexta y una prima". Se ve por las explicaciones de Amat que la guitara española, para la cual escribe, se ajustaba al temple de sol-do-fa-la-re, y ésa habría sido la de Espinel; o sea que la guitarra de Espinel, o simplemente la española, lo único que hizo fué perder y no ganar la prima de la vihuela. La razón parece consistir en que por esa época (y no en el siglo xvir, según piensan algunos autores) debió de extenderse a la guitarra, o popularizarse, el temple subido de un punto, con lo cual la afinación del instrumento se convertía en la-re-sol-si-mi-la. En las vihuelas ambos temples eran corrientes en el xvr, aunque el de la parece que fuera menos utilizado. (Cf. BERMudo, Libro quarto.) Ahora bien, la cuerda de tripa, llevada al extremo agudo, resistía mal esa tensión, sobre todo en las posiciones altas, y se rompía con frecuencia, Su afinación, además, resultaba en ellas poco justa y su empleo no era muy necesario en el rasgueo de acordes a que se iba rcduciendo el acompañamiento. Así, pues, simplemente se suprimió, y se obtuvo la "guitarra española" del xvir, que vemos explicada en Gaspar Sanz con su afinación, ya a diapasón fijo, pues que se atempera al ge-sol-re-ut del órgano (el sol de la cuerda central) y que es la que llega hasta hoy día: la-re-sol-si-mi. El mi grave de las guitarras actuales es añadidura muy posterior y data de la última década del siglo xvıI. Las más veces se dice que fué idea del luthier de Weimar J. A. Otto, en 1790; pero Ad. de Pontecoulant dice en su Organographie, vol II, pág. 71, que cierto Neumann, maestro de capilla en Dresde entre 1789 y 1806,10 había tenido la misma idea. Mahillon, en el Catalogue descriptif

9 También lo menciona en la Galatea, Canto de Calíope.

10 En España se la conoce ya en 1799. Véase el ms. núm. 173 de la Biblioteca Nacional de Madrid: Juan Manuel García Rubio, Arte... para aprehender a templar y puntear la guitarra española de seis ordenes ("según el moderno estilo", añade en el prólogo). Antes de incluirse el mi grave en el tasto - mango de la guitarra se ponían cuerdas graves fuera de él; en algunos instrumentos como la tiorba, a fin de dotarlos de sonidos más profundos que exigían una longitud de cuerdas demasiado grande para que cupieran en el mango del instrumento (cf. anotación xix). Probablemente por esa razón dice Estebanez Calderón en sus Escenas andaluzas (Madrid, 1847, Un baile en Triana): "la guitarra o tiorba rompe primero con un són suave y melancólico por mi menor"; acaso una guitarra atiorbada; al parecer, con el mi que añadió a la guitarra Francisco Rodríguez, el murciano, por esa época, para cantar mejor sus rondeñas. Todavía se oye en Andalucía llamar tiorbas a las guitarras, así como 
et analytique du Musée Instrumental du Conservatoire de Bruxelles, menciona, vol. rv, pág. 430, un Muzykaal Kunstwoorden boek de Verschuere-Reynvaan, publicado en 1795 , donde se habla de una guitarra española de seis cuerdas sobre el diapasón y cuatro al aire; probablemente un archi-cistre, también llamado en España mandora (véase lo dicho acerca de la vandola de Amat) cuando reunía esas diez cuerdas (cf. Mahillon, ob. cit., vol. III, pág. 121). Estas cuerdas graves van relacionadas con la invención del "entorchado". Las cuerdas entorchadas aparecen en el siglo xvir (1620, según M. Brenet; 1675 según J. Rousseau, en el Grove). La manera de afinación indicada en cinco cuerdas hace comprender la indiferencia que siguió en el siglo xvir en el uso de los vocablos guitarra y vihuela, ${ }^{11}$ que ya, prácticamente, apenas tienen diferencia, sobre todo desde que la manera de tocarlas polifónicamente va desapareciendo al dejar paso al nuevo concepto de la monodía acompañada. Con guitarras, laúdes o vihuelas, la antigua estirpe de los trovadores ajuglarados había venido muy a menos en tiempos de Cervantes, quien los moteja de "canalla trovadoresca" (pág. 638 del Viaje) y de "poetas zarabandos" (pág. 692) e incluso en La ilustre fregona los trata de "trovadores de Judas", "que escriben trovas que no hay diablos que las entienda", al paso que en el Coloquio de los perros habla de sus "musas vergonzantes".

InSTRUMentos BÉLICOS.-Puesto que Cervantes fué soldado y tuvo mucho trato con las músicas militares, no dejará de mencionarlas en detalle, casi siempre en un tono lúgubre y ominoso. Con frecuencia se lee acá y allá "trompetas roncas" y "trompetas tristes", "atambores que hacen un són triste y ronco", el cual mudan,

vihuelas. En el mismo cuadrito de Estébanez, de tan vivos colores, se escucha un romance o corrida (corrido en México, que significa romance corrido) tras de habérsele preludiado con "la vihuela y dos bandolines, que formaban lo principal de la orquesta, y comenzó aquellos trinos penetrantes de la prima, sostenidos por aquellos melancólicos dejos del bordón, compaseado todo por una manera grave y solemne, y de vez en cuando, como para llevar mejor la medida, dando el inteligente tocador unos blandos golpes en el traste del instrumento, particularidad que aumenta la atención tristísima del auditorio". Parece que don Serafín alude a los golpes que se dan en la tapa cerca del cordal.

11 Un ejemplo, entre ciento, de esta indiferencia se encuentra en Fray Gaspar DE LOS Reyes, Tesoro de concetos divinos..., Sevilla, 1613, cuyos versos, pésimos, son apenas conocidos:

...es la vihuela

con el músico encordada.

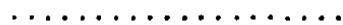

con cinco cuerdas la adorna

más finas que de Alemania

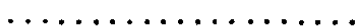

que ha menester pies y manos

cruzado de esta guitarra.

Es de notarse esta alusión a Alemania porque en el siglo xvi, y aun durante mucho más tiempo, las cuerdas para laúdes e instrumentos afines procedían de Bolonia, Roma y Nápoles.

En el Catálogo musical de la Biblioteca Nacional de Madrid, sección de manuscritos, Barcelona, 1946, que ahora llega a costas americanas, existe uno (núm. 166) donde se lee: "Livro/donde se verán Pazacalles de los ocho/tonos i de los tras Puestos. Y así mesmo, Fantazías de conpasillo Proporzioncilla Propor/ción maior, I Compás Maior, I así mesmo diferentes obras Para Biguela hordinaria/que las escribía y asía/Dn. Antonio de Santa/Cruz/Para D. Juan de Miranda." Sin año, añade el catálogo; pero se dice que sus 38 folios son del siglo xvir. Esa hordinariez de la biguela hace pensar que don Antonio no era un retrasado que en el siglo xvir seguía practicando el arte de los Milán, Venegas, Valderrábano, etc., aunque pudiera serlo. A la vista del manuscrito podrá resolverse si la "biguela hordinaria" no era sino una guitarra de cinco cuerdas. En cuanto a la nueva de seis, ya hemos hecho mención del tratado de García Rubio (1799). 
cuando es caso, por un són alegre; "tambores roncos"; en general, "metal ronco". Una orquesta de "cornetas, cuernos, bocinas, clarines, trompetas, tambores" suena junto al "duro estruendo de espantosa artillería" y al disparo de infinitas escopetas, de la artillería y los arcabuces; estrépito que, bien se comprende, habría de dar por tiera con el cuerpo de Sancho, mientras que don Quijote tendría que valerse de todo su corazón para sufrirle (cap. xxxiv de la in parte). Mas Sancho, que sabía que "donde hay música no puede haber cosa mala", pudo acordarse de una orquesta muy diferente (cap. xIx) en otra noche más serena que aquélla, cuando se escucharon "confusos y suaves sonidos de diversos instrumentos, como de flautas, tamborinos, salterios, albogues, panderos y sonajas" hechos por los músicos regocijadores de la presunta boda del rico Camacho y la linda Quiteria.

Los instrumentos bélicos resuenan en los caps. vi y vir del Viaje del Parnaso, en conformidad instrumental con los mencionados y con lo que se lee en varias comedias. Es curioso el papel "inflamador" que Cervantes da a la trompeta:

El són de más de una templada caja y el del pífaro triste y la trompeta que la cólera sube y flema abaja.

Los pífaros se denominan así, alternando con pífanos; las cajas pueden estar "a lo bélico templadas", quizá estirando el parche, a diferencia de los tambores roncos que hemos encontrado antes. "Que celebró la fama con acento sutil en metal ronco", dice Cervantes en una de sus poesías sueltas ("Al conde de Saldaña", pág. 712 de Bibl: Aut. Esp.), de manera que así sabemos cómo sonaba aquella trompeta de la Fama que se escucha en la comedia de la Casa de los celos; "trompetas roncas" en la novela de la Española inglesa, donde mezclándose los sones alegres a los tristes, resonaban unas veces los "clarines regocijados" y los "atambores alegres", a más de los pífanos, ahora llamados así, a los cuales correspondían señales "tristes y lamentables". Esa alegría que Cervantes concede a los clarines frente al tono sombrío de las trompetas, otras veces, es producto de su timbre, resultante de la longitud y anchura del tubo. En los primeros, es propio de su tono más elevado, y por ello en la instrumentación de esa época, que llega hasta mediados del siglo xvin, en las obras de Bach, las trompetas se dividen en dos categorías: clarino, para las más altas, y trompetas segundas, que siguen en orden de registro menos agudo.

Pero qué cosa sea la "trompeta bastarda" que suena en la comedia La casa de los celos, anunciando la aparición de Carlomagno y Galalón, es cosa que no está enteramente clara. El mismo instrumento aparece en los Baños de Argel y los comentaristas y apostilladores de Cervantes, basándose en la opinión de Covarrubias (ed. de 1611), piensan que sea una trompeta entre aguda y grave. Pedrell, en su Emporio científico e histórico de Organografía musical antigua española, título que tan bien va con la época a que se hace referencia, menciona en la pág. 133 cierta Carta de examen de trompeta bastarda datada en Madrid el 27 de diciembre de 1613. Se desprende de ella que la trompeta bastarda se denominaba corrientemente "trompeta española", a diferencia de las italianas, lo que quizá explica por qué no se encuentran referencias en tratadistas extranjeros de instrumentos. 
Pedrell añade (pág. 126, nota) que era "instrumento más artístico y no empleado en la guerra", y cita el romance del Conde Claros:

\title{
Las trompetas y bastardas comenzaron a sonar.
}

No añade Pedrell razones más perentorias que las de Covarrubias, pero sugiere el hecho de que en términos marineros se denominase medias galeras o galeras bastardas cierto tipo de embarcación, sin duda ni grande ni pequeño. En Iñigo López de Mendoza, las trompetas bastardas se mezclan con los clarones, charamías e bonbardas (El Sueño). Las violas bastardas se usaban en el siglo xvi y ocupan un lugar central entre las de su índole (Praetorius, en 1619), mientras que para Cerone, en plena época cervantina, las violas bastardas son simplemente las que no tienen trastes, con cuatro cuerdas, al parecer en instrumentos de distintos tamaños. Pedrell añade que los violones eran instrumentos de la familia de las violas bastardas, acaso basándose en Cerone, lo cual puede explicarse de cierta manera, pero sin que ello arroje luz sobre las trompetas de esa denominación.

La música en las Comedias y Entremeses.-Lo que se ha indicado respecto de las referencias musicales que Cervantes hace en algunas comedias es lo más sustancial de lo que en ellas se encuentra. La titulada El laberinto de Amor es curiosa por su aire tan semejante a las comedias de Shakespeare y su italianismo de fantasía. El quid pro quo que ofrece la elección de marido y el disfraz de las muchachas - de estudiantes o de labradores- para hacer mejor su juego, recuerda aquellas comedias. Versos como los de Julia en la jornada segunda:

\author{
La desdichada \\ prosiguió en voz doliente \\ su historia, en desvaríos comenzada
}

recuerdan también el tono pastoril italiano. La melancolía predomina en la inspiración de esta obra y se expresa en aquellas "trompetas tristes" que hacen el "triste són" con que acompañan al duque de Novara y a los jueces que han de sentarse en un estrado cubierto de luto. Van "los atambores delante sonando triste y ronco" y, a lo lejos, se oyen sonar cajas militares. La escena es curiosa, y los atambores han de ir pintados "la mitad de la caja de verde y la otra mitad de negro, que será extraño espectáculo". Un atisbo de escenografía moderna, podría decirse.

No es mucho más importante lo que se dice en los Entremeses, pero interesan algunas menciones desde el punto de vista del idioma. Las que se refieren a las danzas son mucho más interesantes y requieren párrafo aparte. Por lo pronto, se ve en la música con que terminan los entremeses que la pobre guitarra de sus predecesores se ha convertido en dos, que tañen músicos de oficio, a quienes no ruboriza presentarse en escena. Estos músicos no son solaménte tañedores de instrumentos, sino cantores, y muchas veces sólo cantores. En los Entremeses los encontramos cantan- 
do romances, en algunas ocasiones con estribillos interpolados, como en el la Elección de los alcaldes de Daganzo, donde, por ir vestidos de gitanos, recuerdan la admiración que hacia estas gentes sentía Cervantes por su genio para la música y la danza, según se patentiza en la Gitanilla. El estribillo glosado:

\author{
Pisaré yo el polvico \\ atán menudico; \\ pisaré yo el polvó \\ atán menudó
}

con su acentuación irregular y sus glosas posteriores parece provenir de tiempos atrás; se encuentra ese juego con voces en polifonía durante el siglo xvi, de lo que hay ejemplos abundantes en el Cancionero de Palacio, o de Barbieri. El estribillo del "polvico" se encuentra también en Góngora ("No sólo el campo nevado...", 1615). Como baile lo vemos además en la Gitanilla y en el entremés del Vizcaíno fingido. Otras menciones hay en Quevedo y en bailes y entremeses del siglo xvir, que Cotarelo detalla.xxxvr Trovas, "tan buenas como las de Lope"; glosas y "música concertada", bien que así se la denomine en burla, aparecen en el entremés de La guarda cuidadosa, en el cual la fregona, menos que ilustre, es una cantarina que se acompaña al són de los platos en el fregadero. Su cortejador es también músico, aunque de campanas, dice, porque es sacristán; pero los fuertes en materia de guitarra son el barbero y sus oficiales, que tañen mientras los músicos cantan un estribillo glosado.

Tan chico es el comiquillo que aparece en el Retablo de las maravillas que lleva por nombre Rabelín, y aun Rabelejo, aunque su nombre sea el de Rabel, buen inúsico "de calidad". Sonar se entiende por tocar, pero el sinónimo se emplea para hacer chistes. "Sin cítola y sin són", se añade. ${ }^{2}$ Una trompeta o corneta, indiferentemente, suena dentro del teatro, y los hombres de armas aparecen como llamados "con campanilla". "Villancicos o refranes" se dice en el entremés del Viejo celoso, que parece han de entenderse por estribillos cantados (refrains), aunque ambos vocablos estén empleados en un sentido peyorativo de pejigueras. El "cantar de Gómez Arias", que canta Cristina en este entremés:

12 Dice Benito (pág. 33 de la Colección de Entremeses, ed. Cotarelo): “-Quítenme de allí aquel músico; si no, voto a Dios que me vaya sin ver más figura. ¡Válgate el diablo por músico aduendado, y que hace de menudear sin cítola y sin són!" Benito reniega del músico Rabelín, a cuyo són $\boldsymbol{*}$ despliegan las maravillas del retablo. Por eso lo llama "músico aduendado". A ejemplo de lo que all ocurre, parece como si Rabelín, que es tan chico, pusiera en movimiento la fantasía de las gentes, aun "sin cítola y sin són", o, a lo menos, tan malos como los de Rabelín. "Sin cítola y sin són" parece que sea algún dicho popular, pero, en todo caso, resulta muy apropiado poner una cítola en manos de Rabelín.

La cítola era, en los casos más antiguos, la especie más pequeña de la vihuela de péñola, no más grande que el rabé morisco (el cristiano se toca con arquillo y el morisco se tañe con los dedos) como puede verse en las miniaturas de las Cantigas. En la núm. Ix (ed. Ribera) el de la izquierda tañe una cítola con una púa, y el de la derecha afina otra, ambas de tres cuerdas. Se las puede comparar con los rabeles de arco de la miniatura núm. xI. Todos son instrumentos pequeños, de figura piriforme alargada; éstos, todavía más chicos que aquéllos, que, como claramente se advierte, se tańen con púa. La diferencia principal consiste en sus clavijeros, doblados en ángulo recto, al modo oriental, los del rabé, y que en la cítola y en la rebeca de al lado (si no es también una cítola) rematan en una curva airosa. Se ven juglares de cítola en miniaturas y pinturas espaffolas de la época. 


\section{Señor Gómez Arias \\ doléos de mí; \\ soy niña y muchacha; \\ nunca en tal me vi}

ha sido señalado por Henríquez Ureña como un caso de "endecha", al modo del cantar viejo de los Comendadores de Calatrava:

\section{Los Comendadores \\ por mi mal os vi,}

que tuvo mucha repercusión en la lírica y teatro españoles por más de doscientos años y que don Lázaro Núñez-Robres recoge, con su música, en su colección de cantos españoles La música del pueblo, Madrid, 1869, considerándolo como romance tradicional. Menéndez Pelayo piensa que se encuentra ya una glosa de este romance o endecha a fines del siglo $\mathrm{xv}$.xxxvir

La música que se menciona en el Gallardo español es toda ella de carácter belicoso: atambores, clarines, trompetas y cajas que acompañan a un escuadrón de turcos; chirimías y cajas para anunciar la llegada de las altas personalidades mahometanas; después, serán las campanas las que anuncien la gran alegría, con chirimías también, por el socorro que dan a Orán las galeras de don Álvaro Bazán, y claro está que éstas y aquéllas serán tañidas por cristianos, pues que como don Quijote sabe muy bien, y así lo advierte al trujamán del Retablo de la libertad de Melisendra, "entre moros no se usan campanas, sino atabales, y un género de dulzainas que parecen chirimías". Los moros, en el tumulto de sus atambores, hacen mucha vocería de "¡li, li, li!" o "lililíes al uso de moros", como se dice en Don Quijote en varias ocasiones.xxxvin $\mathrm{El}$ hecho de que el nombre de un instrumento designe también a la persona que lo toca se encuentra claro en el Entremés de los dos habladores con relación al atambor, de quien allí se habla; era cosa corriente en Italia al comenzar el siglo xvi.

De la música en la comedia de la Casa de los celos se ha hecho mención ya. Queda por anotar el paso de ballet a la francesa que se celebra en el palacio del emperador Carlomagno. La bella Angélica viene sentada sobre un palafrén, que "traen de la rienda dos salvajes vestidos de yedra o cáñamo teñido de verde". También se verán así en las danzas que se celebran en las bodas de Camacho el rico; pero mucho tiempo antes se habían visto con ese indumento y malas trazas en los autos que Lucas Fernández organizaba para las fiestas del Corpus en la catedral de Salamanca.

Los romances con estribillo que se cantan en los Baños de Argel han de hacerse al són de "las guitarras y el rabel" que traen los mozos cristianos, aunque salgan vestidos a la turquesca, mientras que el llamado Ambrosio canta, sin acompañamiento, el zéjel antes mencionado:

Aunque pensáis que me alegro conmigo traigo el dolor. 
Músicos moros aparecen en la tercera jornada de esta comedia, pero son músicos cantores, "música hereje" que acompaña a un coloquio de Lope de Rueda que por diversión allí representan, sin mejor indicación de música que la de "canten lo que quisieren". Acompañando a la novia salen los moros y cristianos que van a la boda "con música y hachas encendidas, guitarras y voces y grande regocijo, cantando los cantares que yo dare", pero no aparecen por ninguna parte, por lo cual se deduce que era ésa una acotación de Cervantes a la vista de alguna representación de la comedia. Y esta vez el sacristán de turno, "músico divino", en vez de tañer campanas, es con una guitarra con lo que va a celebrar su libertad. Ahora volverá a encontrar las campanas por las que suspira de tan lírica manera:

iOh campanas de España!

¿Cuándo entre aquestas manos

tendré vuestros badajos?

¿Cuándo haré el tic y toc o el grave empino?

No sabemos qué cosa sea el grave empino en el vocabulario campanil (empino es elevación o altura, como el voleo de la campana, cuya gravedad estaría en el tono de ella); pero sí resulta más claro aquello otro de

Toco el din y el don y el dan a cualquiera hora del día.

En el Rufián dichoso nos encontramos con un instrumento de metal que, usándose como bajo de las trompetas, a cuya familia pertenece, no habíamos escuchado todavía: es el sacabuche, o, simplemente, trombón de varas, nombre tomado del francés, sacquebute, por la acción de sacar y meter el tubo metálico de cuya longitud depende el sonido que se obtenga. Pero encontramos el vocablo, un poco ridículo en castellano, no en boca de músico, sino de un criado que lo emplea en ese sentido burlesco. En el mismo són de burla se dicen ser "cantaletas" las "matracas" nocturnas, a guisa de serenatas dadas con mala intención y peor música. No tiene sentido más fino el "guitarresco són" con que se acompaña cierto baile, una vez que dos músicos con sendas guitarras han dado su serenata.

En esta obra encontramos aquellas apariciones angélicas por cuya acción de tramoya suspiraba Cervantes en el prólogo de sus Comedias. Pero, prudentemente, soblo dice: "descúbrese una gloria, o por lo menos un ángel", que pone fin al acto primero tras una tocata de chirimías; música celestial, como hemos visto, para Cervantes, que une las chirimías a las flautas cuando se trae el cuerpo santo del que fué un rufián en vida. Pero, cuando nos encontremos con un corista en la jornada segunda, no hemos de pensar que se trata de ningún miembro del coro de un teatro, sino, precisamente, del coro de iglesia. El rufián convertido se dice que sea rezador de "psalmos penitenciales", es decir, no cantados.xxxix El "punto" es, como se sabe, la nota musical, que por extensión se entiende, desde tiempo atrás, como la música en que se funda alguna canción o danza, tal aquella trisca a la cual daba el punto la guitarra morisca del Arcipreste. "Entone más bajo el punto de cortesía", dice el padre Cruz a Fray Antonio cuando le saluda reverenciosa- 
mente. Del "entono" se dice en Don Quijote xu que es, además, "el tono de la habla". "Cantar, no a tono de instrumentos", se dice en el Persiles. Templar se dice en aquella comedia de una guitarra, pero en Don Quijote, un arpa se afina.xu "Afinada la harpa", a fin de que Altisidora cante su romance:

¡Oh tú que estás en tu lecho

entre sábanas de holanda...!

Pero ajustar un instrumento con otro es "acordarlos" entre sí. "Acuerda tu instrumento con el mío", se dice en la jornada segunda del Gallardo español. (Cf. Dante, Purgatorio, vir, 112-113.)

Las guitarras frecuentemente se tocan a la par que las sonajas, especialmente cuando han de acompañar las danzas.xur En esta comedia se trata de acompañar cantos a lo rufo y de jacarandina. En la Gran Sultana dos músicos cantan mientras los acompañan con guitarras y sonajas.

Vuélvanse a repicar esas sonajas, háganse rajas las guitarras, vaya otra vez el floreo...

se lee en Pedro de Urdemalas.

Aquella armonía de los pajarillos, tantas veces reiterada en la poesía pastoril, se contrae ahora a más parcas voces, pues que un solo ruiseñor basta para el caso:

\section{Un ruiseñor pequeñuelo \\ que con divina armonía}

iba diciendo algo que es un "cántico"xurn con su misterio dentro. En la música turquesca de la Gran Sultana son las chirimías las que hacen el gasto; pero al fin de la comedia se las ve celebrar la alegría por la doble cualidad de doña Catalina, gran sultana y cristiana a la par.

Una especie digna de mención dentro del romance aparece en esta comedia. El llamado Madrigal dice que, aunque danza como una mula, va a cantar un "romance correntío", cosa suelta y ligera y, además, añade que lo piensa cantar "a la loquesca", lo cual no anda lejos de las folías que se van a cantar allí mismo, con varias danzas de las que ha de hablarse. "Al tono correntío y loquesco" es como Preciosa canta su romance "Salió a misa de parida" en la Gitanilla, tono que no parece corresponder con el piadoso del romance.xurv

Todavía se usaban en ticmpos de la Entretenida los motes como pasatiempo social, aunque ya se iban haciendo junto a "cuentos, chistes [y] dichos", al modo de lo que se hacía en la corte valenciana de Germana de Foix mediando el siglo,xuv según nos lo describe el vihuelista don Luis Milán. No se habla en esta comedia con menos finura que en aquel tratado de cortesanía, y sí encontramos esta linda definición de consonancia y disonancia:

El discreto es concordancia que engendra la habilidad; 
el necio, disparidad

que no hace consonancia,

pues que concordancia "es el fin de la música" según se dice en el Persiles (pág. 638) y ya que, además, "la música compone los ánimos descompuestos y alivia los trabajos que nacen del espíritu" (Quijote, I, 33). Cervantes denomina semínima en la Entretenida y en Don Quijote a la semimínima,xuvi aun cuando escriba normalmente el punto de doble longitud de ésta, o sea la mínima. Semínima se encuentra en Narváez (El Delfín de música, Valladolid, 1538) y en Venegas de Henestrosa (Libro de cifra nuevo, Alcalá, 1557), pero también se encuentra semimínima en otros autores españoles del siglo xvi. Así se ve en el Tratado de glosas sobre cláusulas de Diego Ortiz, en 1553, aunque debe recordarse que Ortiz escribía en Italia y que publicó su tratado en Roma. En viejos tratados castellanos se encuentra el vocablo escrito como semínima y así lo escribe Nassarre en la segunda mitad del xvIr (Fragmentos músicos..., Zaragoza, 1683) llegando a los diccionarios de música como el de Melcior (Lérida, 1859) y a los diccionarios de la lengua hasta el dáa, como el de la Academia, por más que semínima sólo en ellos se encuentre y no en el lenguaje usual, vulgar o técnico.

"Musiquillo de mohatra" se llama despectivamente a cierto cantor; y, no más amigablemente, un alguacil pregunta: “¿Qué guitarra es ésta?", en un sentido de 'tumulto' o 'pendencia'.

No hemos encontrado aún la "gaita zamorana", que aparece en la comedia de Pedro de Urdemalas, con la particularidad de que puede tocarse en ella no importa qué clase de música, pues se dice: "Suena dentro todo género de música y su gaita zamorana", que ha de querer decir que suena la gaita a más de las otras músicas. Pero la gaita zamorana no tiene nada que ver con las gaitas de pellejo, del tipo de la musette, sino que es un instrumento de caña doble, corto y ancho, de sonido duro y penetrante, que con el nombre de dulzaina se toca en muchos sitios de la Península, y que en Argel y Marruecos tañen los árabes con el nombre de gaita, acaso como importación española. Lvir (Es el instrumento mencionado por don Quijote, sin que le dé nombre, en el Retablo de la libertad de Melisendra.)

Farsante y farsista es, en esta comedia, el cómico que trabaja en las farsas y, por extensión, en las comedias. Ésta termina con las guitarras que tañen los comediantes y con el romance que cantan los músicos, que califican de pandero al más bobo y zafio de los pretendientes al oficio de farandulero:

Proceda examen primero,

o muestra de compañía,

y no por su fantasía

se haga autor un pandero.

La música en las Novelas ejemplares.-Las referencias que Cervantes hace a la música en sus novelas todavía descienden de tono respecto de las que hemos visto en sus comedias; menos abundantes que en éstas, aunque las danzas toman el principal interés, igual que en los entremeses. La Gitanilla es la que con mayor generosidad ofrece lo uno y lo otro; porque danzar y bailar es el oficio de los gitanos, a 
quienes en la comedia Pedro de Urdemalas hemos visto guiados por un "conde de gitanos", el cual habla con su peculiar ceceo, "que es artificio en ellos, que no naturaleza":xuvm

Mira Pedro: nueztra vida

ez zuelta, libre, curioza, ancha, holgazana, eztendida, a quien nunca falta coza que el dezeo buzque y pida...

Como se habla a seguida de las danzas en general, sólo mencionaremos ahora las referencias a otros aspectos de la música que Cervantes hace en las Novelas ejemplares.

Desde el primer momento aparecen en la Gitanilla las danzas y los gitanos. Los cantares también, pues que Preciosa era "rica de villancicos, de coplas, seguidillas y zarabandas y de otros versos, especialmente de romances, que los cantaba con especial donaire" sin más acompañamiento que el de unas sonajas, según se ve, y que es acompañamiento que merece señalarse, al tiempo que daba "en redondo largas y ligerísimas vueltas" delante de la iglesia. Eran cantares monódicos; pero los que, líneas abajo, cantan tres muchachas, con sonajas, "todas apercibidas de romances y de cantarcillos alegres, pues que ni Preciosa cantó jamás cantares descompuestos ni permitía que los cantasen en su compañía", parece que no habrían de ser en tres voces en polifonía, sino, cuando más, alternativas, según hemos visto en algún caso en las obras pastoriles. Las seguidillas, como canto, se encuentran en Rinconete $y$ Cortadillo, en unas muy señaladas:

\author{
Por un sevillano, \\ rufo a lo valón, \\ tengo socarrado \\ todo el corazón.
}

Esos versos son suficientes para comprender el significado y origen del vocablo flamenco que se da a determinada música andaluza, más que propiamente gitana, y sobre cuya procedencia se han hecho las más descabelladas suposiciones. Las sonajas de Preciosa son castañetas en manos de sus compañeras, que bailan al són de ellas y del tamboril: tejoletas en otras ocasiones más simples, cuando las hace Monipodio xux con dos cachos de platos puestos entre dos dedos y repicados con fuerza. En su forma de tejoletas o de crótalos, las castañuelas figuran entre los instrumentos más antiguos de la humanidad, pues que se encuentran ya representadas en los relieves egipcios de la vieja dinastía, alrededor de tres mil años antes de nuestra era; pero, aunque crótalos griegos y crusmata latinos llegaran a adoptar la forma conocida que reproduce la de una castaña cortada por la mitad, de arriba abajo, el nombre de castañuelas no procede de esa forma ni instrumentos. Su nombre castizo, que es el de castañetas, como en Cervantes, significa el ruido que se hace al chascar con fuerza los dedos pulgar y medio, y este modo de tocar los pitos (según se dice popularmente en Andalucía, donde las castañuelas se denominan palillos) está representado con toda claridad en el relieve mural de lá tumba de Nensheftkai, en 
Sakhara, perteneciente a la época de la quinta dinastía egipcia, hacia el año 2700 a. C. $\mathrm{L}$ Los cascabeles de que habla el Repolido, un momentos antes, para tocarse a la par con un pandero, puede que sean en este caso simples sonajas, acaso de metal más recio, mejor que no los cascabeles menudos que, colocados en los calcañares, acompañan las danzas de este nombre. Las sonajas pueden ser de dos maneras: insertas en un aro de madera, que, cuando está cubierto con una piel, forma la pandereta, o prendidas en unos alambres que recoge una montura de metal: tales son los sistros egipcios, que eran instrumentos sagrados, dedicados a la diosa Isis y que no por nada habrían conservado milenariamente los gitanos, que a sí mismos se suponen procedentes de aquella parte de África Oriental.ur

La pandereta era el panderete en Cervantes:

Cuando Preciosa el panderete toca y hiere el dulce són los aires vanos, perlas son que derrama con las manos...

Por más que ese arte fuese notable, era mejor, sin duda, el de improvisar silvas, alternadamente, en sendas guitarras, según lo hacen Andrés, al pie de un alcornoque, y Clemente, al de una encina. Preciosa los interrumpe con un romance, acaso improvisado, que detiene las manos de los dos instrumentistas y su canto.

En la novela del Amante liberal no hay mención de música, pero puede recogerse la mención del cadí "haciendo la zala en la mezquita"; es la zalá u oración canturreada de los musulmanes.

Las tejoletas que hemos visto en manos de uno de los más conspicuos personajes de Rinconete y Cortadillo acompañan a la música grotesca que hace la Escalanta golpeando un pandero con su chapín, mientras que la Gananciosa, con una escoba de palma, interviene en el trío. No sabemos cómo se las compuso para rasgar la escoba, pero sin duda fué de manera notable, pues que "espantó" a Rinconete y a Cortadillo con la novedad de la invención, la "más presta y más sin pesadumbre ni más barata" que se había inventado en el mundo. Maniferro menciona la opinión de un estudiante letrado, el cual alude a Marión, "que subió sobre el delfín y salió del mar como si viniera caballero sobre una mula de alquiler". Marión, se entiende, no es sino el famoso Arión que, a lomos de un pez de la clase mencionada, llegó a la tierra firme de Grecia procedente de las costas cercanas del Oriente, a fin de organizar las fiestas del Ditirambo, en honor de Dionysos. Pero marión es vocablo peyorativo con que Cervantes designa a los afeminados, aunque, es de suponer, nada tenga que ver con las danzas denominadas marionas. ${ }^{13}$ La música de la escoba era sin

13 No hay marionas en Cervantes, pero, como música, aún se las encuentra en las cifras para guitarra en España en los primeros años del siglo xviIr. Esquivel Navarro supone que eran igual al Rastro (Cotarelo, ob. cit., pág. cClinI). Parece que la mención más antigua se encuentra en el Diablo cojue. lo, de Vélez de Guevara, junto con otros bailes de la primera mitad del xvir. Un par de décadas después (1663) aparecen en los entremeses, juntamente, en algunos casos, con los matachines. Si la proximidad de ambos bailes significa algo pudiera indicar un origen quizá francés para aquella danza. Los eruditos cuya consulta tengo a la mano no dicen nada respecto de su origen. Por lo que pueda servir, añadiré que según Allardyce Nicholl, Masks, Mimes and Miracles (London, 1931), "está ampliamente probada la popularidad, en los tiempos romanos, de los moriones, o locos caseros. Había un mercado regular de locos (forum morionum) en Roma, y Marcial los describe con su cabeza puntiaguda y largas orejas que movían como los asnos". Quizá este delicado particular contribuyó al atuendo 
duda de un són ronco y áspero, pero el instrumento resultaba "fácil de deprender, mañero de tocar y sin trastes, clavijas ni cuerdas" como las habituales en la guitarra. Con esa música se cantan seguidillas de versos de seis más cinco sílabas:

\author{
Por un morenico \\ de color verde \\ ¿cuál es la fogosa \\ que no se pierde?,
}

música que parece demasiado complicada al Repolido, quien pide que "se cante a lo llano". No sabemos si los mencionados instrumentos serían los que en la Española inglesa se suponen permitidos a una doncella bien nacida, aunque fácil de presumir es que no, dada la educación que se daba a aquella damisela, que "en lo que tuvo extremo fué en tañer todos los instrumentos que a una mujer son lícitos y esto con toda perfección de música, acompañándola con una voz que le dió el cielo, tan extremada, que encantaba cuando cantaba". El viejo juego de palabras agradaba a Cervantes, que lo emplea también en la comedia del Rufián dichoso. Allí es donde encontramos entre los instrumentos optimistas los "clarines regocijados" y los "atambores alegres", y entre los pesimistas las "trompetas roncas" y los "pífanos con señas tristes y lamentables". "Negro y pizmiento" es, en Don Quijote (II, 36), el "pífaro" que suena junto a dos tambores enlutados, en un són "tristísimo y melancólico".

En el Celoso extremeño, el llamado Loaysa muestra su habilidad como instrumentista, puesto que en una guitarra "algo grasienta y falta de algunas cuerdas" era capaz de tañer "sones alegres y regocijados", mientras que como cantante se producía entonando romances de moros y moras, según aquella manera loquesca. No era menos bueno como maestro el tal Loaysa, quien enseñaba a "tañer a algunos morenos y otra gente pobre" y decía tener ya enseñados a "tres negros esclavos de tres veinticuatros" (que eran los regidores en algunos ayuntamientos de Andalucía), de tan buena manera que "pueden cantar y tañer en cualquier baile y en cualquier taberna y me lo han pagado muy rebién". El negro Luis siente envidia, ya que no tiene mala disposición, pero sólo conoce tonadas anticuadas como la de la Estrella de Venus. Loaysa encuentra que "a juzgar por el órgano de la voz, que es atiplada, debéis cantar muy bien" (el pobre negro pertenecía al género epiceno de los evirati), pero "la mejor voz del mundo pierde sus quilates cuando no se acompaña con el instrumento, ahora sea de guitarra, o de clavicímbano, de órganos o de arpa"; aunque lo que al negro le conviene es la guitarra, "por ser el más mañero y menos costoso de los instrumentos", a seguida de lo cual le da consejos para conservar la buena voz. Como ejercicio le canta Loaysa algunas "tonadicas nuevas" y un "romancito agudo" siempre en su guitarra, tocada "baja y suavemente", y que; ahora a lo menos, estará "bien encordada y mejor templada". De este modo Loaysa ofrecerá a las criadas de la casa un recital que comenzó tocando el "Pésame dello", tonada de danza, para acabar "con el endemoniado són de la zarabanda" al cual se estimaba

característico de los fous medievales, folletos en España. El diccionario latino de Valbuena los conoce como "morio-morionis: necio, fatuo, simple, que hace reír con sus naturales simplezas", refiriéndose al testimonio de Marcial. Como la danza de matachines, las marionas debieron de ser danzas bufas. 
como introducido poco antes en nuestras tierras. Fué grande el regocijo de las que escuchaban, quienes se hicieron pedazos bailando. Por fin, Loaysa echa "un sello al gusto" cantando algunas "coplillas de la Seguida". Todos quedaron "muy contentos del concierto". Ya rayaba el alba cuando Loaysa daba lición al negro, cuyas buenas dotes alababa mucho, pues que le convenía, aunque el pobre no sabía, "ni lo supo jamás, hacer un cruzado", la más fácil postura de los dedos sobre los trastes de la guitarra.

Los amigos de Loaysa avisan de su nocturna presencia con la señal convenida, "que era tocar una trompa de Paris". Es pintoresco que comentaristas de Cervantes como Rodríguez Marín digan, con acopio de datos, sir que la trompa de Paris era un instrumentillo como los llamados birimbao, guimbarda o jews harp, trozo curvo de acero sujeto entre los dientes del tañedor. Una laminilla vibra produciendo un sonido musical, tan flébil que apenas lo puede escuchar sino quien lo toca. La vibración repercute en la caja craneana, como cuerpo de resonancia, y permite cierta tecnica siri y música agradable, pero en extremo apagada, con lo cual no se comprende cómo los amigos de Loaysa podrían avisar a éste desde la calle. Por el momento será menester conservar el incógnito a este instrumento cervantino, que ningún tratadista en estas materias menciona ni menos explica.

Los ronquidos del extremeño, tras del alopiado ungüento con que le untan, suenan a la joven y decepcionada esposa como "la más acordada música". El participio era viejo ya entonces, pero este es el tiempo en que las notas coincidentes que han de darse "de golpe" en la guitarra, en vez de punteadas, van a tomar el nombre genérico de acorde. Por fin, Loaysa tañe en su guitarra "unas coplillas que entonces andaban muy validas en Sevilla" y eran las que decían:

Madre, la mi madre, guardas me ponéis, que si yo no me guardo no me guardaréis,

las mismas que glosó la dueña de la casa "con más gusto que buena voz" (así, se dice también en Don Quijote "gusto el canto", o "en el canto", il, 67) y danzaron todos los demás concurrentes. El hecho de que se diga aquí "el corro de las mozas" para significar a las bailadoras no parece indicar la forma de la danza, sino que corro debe de tener sólo sentido colectivo.

Si esa coplilla corría por Sevilla, la de los "tres ánades, madre" era la que estaba de moda en Castilla por el tiempo en que los jóvenes Carriazo y Avendaño bajan desde Burgos hasta Toledo, en cuya posada del sevillano encontrarán a la protagonista de la Ilustre fregona. La coplilla era añeja, sin embargo. Juan de Anchieta la había puesto en música quizá a fines del siglo xv (era capellán cantor de los Reyes Católicos en 1489). Con el tiempo, los ánades, que eran dos en este músico, aumentan en número:

Dos ánades, madre, que van por aquí, mal penan a mí. 
Quevedo también conoce el villancico con sus tres aves; pero Barbieri está en lo justo al pensar que la versión más vieja es la que mejor se comprende, pues que se añade: "Al campo de flores / iban a dormir". Es decir, una parejita de ánades que por algo darían celos al cantor.urv "Seguidillas como en estampa", "romances con estribos" eran cosa usual. El soneto que escuchan, dedicado a la moza "al són de la arpa y de una vihuela" era música de más fina estirpe, que ahora vemos descendida al nivel vulgar de un mesón.tv Carriazo piensa que es día de fiesta en el próximo monasterio de Nuestra Señora del Carmen y que tocan al alba las chirimías: éstas no eran sino las de aquellos músicos que con ellas se despedían de su madrigal. Lo que se canta y se baila en la posada, con la concurrencia de muchos mozos de mulas, es interesante, y va a la cuenta de lo que se dirá después sobre las danzas. La música no pasó de ser una guitarra, tañida por un asturiano, "que decían que la hacía hablar", tópico que Cervantes aplica asimismo al mancebo Basilio, quien, para usar otro tópico, cantaba "como una calandria" (Don Quijote, II, 19). Cuando las mozas pidieron al asturiano Lope que cantase algún romance, dijo éste "que como ellas le bailasen al modo como se canta y baila en las comedias, que le cantaría". En contraste con semejante música de fregatrices y mulantes, un hombre, sentado sobre una piedra frente a la posada, cantaba "con maravillosa y suave armonía"; mas no al gusto de todos, pues que le obsequiaron con dos medios ladrillos. "¡Infelice estado de los músicos, dice Cervantes, murciélagos y lechuzos, siempre sujetos a semejantes lluvias y desmanes!" Más tarde se escuchan unos ovillejos que estaban escritos donde menos se piensa: en el libro de cuentas de la cebada.

En la novela de la Señora Cornelia no aparece referencia musical alguna, sino una mención de una "trágica comedia", según se decía "drama jocoso" de algunas óperas. En la del Casamiento engañoso se dice "bailar el agua" en el sentido que todavía se da a la frase de "hacerle la barba" o adular a alguno. Más abundante en menciones musicales es el Coloquio de los perros. Allí se encuentra en seguida una relación de lo que los viejos clásicos del siglo xirr habrían denominado instrumentos "de comunales maneras", tales como el golpear de dos cayados, uno contra el otro, las tejuelas y atambores, al lado de los cuales se ven los "instrumentos extraordinarios" - que son los que tañen "los pastores de los libros", fuente de la musicología cervantina que se acaba de describir-: gaitas, zampoñas, rabeles, churumbelas, caramillos "y otros" del mismo jaez, a cuyo tono respondían, en los libros, las "canciones acordadas y bien compuestas", al paso que los pastores reales de Berganza cantaban con voces tan roncas que, "solas o juntas, parecía, no que cantaban, sino que gritaban o gruñían", y era un "cata el lobo", “do va Juanica”, y otras cosas por el estilo. (Así en Bibl. Aut. Esp. "Cata el lobo do va, Juanica" se encuentra en Salinas, De música..., 1577. Cf. Henríquez Ureña, La versificación irregular, pág. 195, n. 2).

No mejor condición que los farsantes, que en tan triste estado nos pintaron Cervantes y Rojas, tienen los titereros, tan abundantes en España en ese momento (y no hacía mucho que habían llegado xur con sus retablos), que lo que ganán cada día vendiendo coplas apenas alcanzaba para sustentarlos. Los gitanos aparecen en esta novela en un rancho cerca de Granada y les guía cierto conde Maldonado. 
Sobre sus primores acostumbrados tenían los de ser volteadores (es decir, lo que hoy se entiende por titiriteros), corredores y bailadores. Era aún la época en que los moriscos poseían huertas en aquella región andaluza. Los farsantes, guiados por el autor de comedias Angulo el malo, no tenían mejor inspiración que la que les prestaban sus "musas vergonzantes" y, con ello, el mejor recurso para terminar los entremeses era hacer que acabasen a palos: final clásico. De manera que cuando Cervantes en la Gran Sultana atribuye al actor Alonso Martínez, que formaba parte de la compañía de Jerónimo Velázquez, en 1590, la invención de los bailes cantados con que terminan algunos entremeses, debe entenderse (según se dijo antes a propósito de invención) que el tal Alonso tuvo la ocurrencia y originalidad de hacer que los entremeses concluyesen, no a palos, sino con danza y canto, como ocurre en los de Cervantes mismo.

Sea o no de Cervantes, la Tía fingida, lo mismo que las novelas anteriormente examinadas, interesa por sus referencias musicales, bastante abundantes y hasta cierto punto mejor circunstanciadas que en las anteriores. La serenata con que se obsequia a una dama tenía una plantilla instrumental copiosa: cuatro músicos de voz y guitarra, un salterio, una arpa, una bandurria, doce cencerros y una gaita zamorana: cencerros y bandurria citados por primera vez hasta ahora. A más, treinta broqueles para hacer estruendo, que no sería poco junto a "los crueles cencerros". El arpa acompaña un soneto cantado, y la gaita zamorana toca el són de dos danzas: las gambetas y el esturdión. "Pero, con todo eso, al són de las guitarras segundaron a tres voces con el siguiente romance..." En ninguna otra ocasión se menciona taxativamente que los instrumentos secunden el canto a varias voces. "Volvieron a hacer la refacción de la música con algunos villancicos; volvió a sonar la gaita y el enfadoso y brutal són de los cencerros, con el cual ruido acabaron su serenata". Y las Novelds.

LA MÚSICA EN "Don Quijote".--Hay pocas menciones en el Quijote que representen una novedad respecto a lo ya dicho en punto de instrumentos, aunque hay algunas elocuentes. Los instrumentos pastoriles y los bélicos son los que ya hemos visto aparecer. Las danzas no son las tan del agrado de las gentes de las novelas y entremeses, sino que pertenecen a un género más importante como arte, según se dirá en seguida. El Caballero del Bosque (II, 12) se prepara para cantar su soneto y para ello se pone a templar cierto instrumento. Don Quijote no entiende bien de cuál se trata: "templando está un laúd o vihuela", dice, y ello nos aclara la manera en que ambos instrumentos se tañían, indiferentemente, en la España del siglo Xvi, y aun todavía a la altura de esta segunda parte, en la segunda década del xvir. Pero la confusión o indiferencia de don Quijote al referirse a ambos instrumentos no es ignorancia suya, pues que en el capítulo xLvi pide a la doncella amiga de Altisidora que le pongan un laúd en su aposento, a fin de apaciguar con su canto las penas de amor de aquella doncella; la cual, volviendo en sí de su desmayo, dice a su amiga: "Menester será que se le ponga un laúd; que sin duda don Quijote quiere darnos música, y no será mala, siendo suya". Mas, cuando entrada la noche se retira el Caballero a su recámara, lo que encuentra allí es una vihuela. No le importa el cambio, pues que sólo había una diferencia de nombres más que de instru- 
mentos. Templa sus cuerdas, y, "habiendo recorrido los trastes de la vihuela y afinándola lo mejor que pudo, escupió, remondóse el pecho, y luego, con voz ronquilla, aunque entonada, cantó el siguiente romance, que él mismo aquel día había compuesto:

Suelen las fuerzas de amor sacar de quicio las almas..."

Los laúdes unidos a las arpas hacen una "agradable música", a cuyo compás viene "un carro de los que llaman triunfales", tan del gusto renacentista (cap. xxxv). Dentro de él sonaba csa música, en tanto que las chirimías acompañaban la presencia de los Duques: Todos los instrumentos callan y la muerte comienza a decir, "con voz algo dormida", sus versos famosos:

Yo soy Merlín, aquel que en las historias...

Esta música, "suave y concertada", venía a contrastar con la que acababa de oírse en el capítulo anterior, anunciada por el són de un cuerno; tan ominoso, que Sancho no pensaba volver a escucharlo sino en Flandes. En el interior del bosque se mezclaban el estruendo de las armas de fuego y la gritería de los combatientes, siquiera fuese fingida, a los instrumentos bélicos que quedaron antes detallados. No es esta música estrepitosa, ni aquella otra más propia de camarín o de sala, música de instrumentos altos la una, de instrumentos bajos esta otra, la que suena en la campiña que va a servir de escenario a las bodas del rico Camacho. "Era anochecido - se lee en el cap. xix-, pero, antes de que llegasen, les pareció a todos que estaba delante del pueblo un cielo de innumerables y resplandecientes estrellas", y se oye el murmullo confuso aunque deleitoso de los instrumentos pastoriles también citados antes. "Los músicos eran los regocijadores de la boda, que en diversas cuadrillas por aquel agradable sitio andaban, unos bailando, y otros cantando, y todos tocando la diversidad de los referidos instrumentos..." Cuando llega el momento de las danzas y representaciones, unas doncellas aparecen guiadas por el són de una gaita zamorana; en seguida, los salvajes, en aquel conocido atuendo, tiraban de un castillo de madera mientras que "hacíanles el són cuatro diestros tañedores de tamboril y flauta"; instrumento, el tamboril, que al ser denominado en plural se dice ser tamborinos -pues que también se nombra tamborín (II, 67)- Otros instrumentos pastoriles aparecen acompañando la escenificación del romance de don Gaiferos, en el retablo de Maese Pedro (cap. xxvi), donde don Quijote hace gala de su erudición en materia de organografía, y no por única vez, pues a seguida se dirá cuál es su opinión sobre los instrumentos llamados albogues, que nos ofrece juntamente con su conocimiento de la lengua arábiga; así resulta de tradición el encontrar arabistas y musicólogos todo en una pieza.

Chirimías son las que reciben a Sancho, como si fuera un duque, en su ínsula, cuando llega a comer, tan serio como "juego de maesecoral", Lvir frustrado banquete que termina con el són de una corneta de posta, anunciadora de la llegada del Duque.

Hay un pasaje en el cap. Liv que muestra andantes todavía por los caminos 
de España a los peregrinos tudescos, bien que Sancho los llamase franchotes, quienes hacían su peregrinación pidiendo limosna, guelte, a los oídos de Sancho, lo cual se entendía como dineros, o sea geld, o geldes. "Juntéme con estos peregririos -dice el disfrazado morisco Ricote-, que tienen por costumbre de venir a España muchos dellos, cada año, a visitar los santuarios della, que los tienen por sus Indias, y por certísima granjería y conocida ganancia. Ándanla casi toda, y no hay pueblo ninguno de donde no salgan comidos y bebidos, como suele decirse, y con un real, por lo menos, en dineros, y al cabo de su viaje salen con más de cien escudos de sobra..."Lvirr

Los interlocutores de Cervantes gustan a veces mostrar su conocimiento, no muy refinado, de la lengua italiana; pero don Quijote sabía de sus escritores algo más, bien que traducidos, y menciona entre éstos al doctor Cristóbal Suárez de Figueroa por su versión del Pastor Fido y a don Juan de Jáuregui por la de Aminta, "donde felizmente ponen en duda cuál es la traducción, o cuál es el original". Sabemos que tenía en su biblioteca los Diez libros de Fortuna de Amor del sardo Antonio Lofraso (Antonio de Lo Frasso), quien escribía en castellano sus disparates que tanto divertían al cura escrutiñador, tan docto, y que sabía leer italiano de corrido hasta el punto de no querer perdonar al cristiano poeta Ludovico Ariosto si lo hallaba hablando en otra lengua que la suya, al paso que "si habla en su idioma, le pondré sobre mi cabeza", y además sabemos que las estancias que don Quijote cantaba del gran modenense estaban en su idioma vernáculo, ${ }^{14}$ suponiendo nosotros que el músico que las llevó al pentagrama sería también italiano.

Don Quijote conoce, pues, al pormenor los instrumentos musicales que aparecen en esas obras y en otras españolas ya mencionadas, y que se vuelven a presentar en el cap. Lxvir, desarrollado en la supuesta pastoril Arcadia con el pastor Quijotiz, el pastor Pancino, el pastor Sansonino o Carrascón y el pastor Curiambro, que era el cura, cuyo nombre de pila se le había olvidado. Los primeros sones que llegan a sus ilusionados oídos son los de unas churumbelas, seguidas de gaitas zamoranas, tamborinos, sonajas, rabelcs, entre cuyas "diferencias de músicas". (que parece han de entenderse aquí como variedades de matices o conjuntos de timbres y no lo que en el tiempo se entendía por diferencias y más tarde por yariaciones) resuena la de los albogues, instrumentos que, atendiendo a su etimología arábiga, donde se denominan como al-buk (buk, probablemente por buccina) son aquellos que en los más viejos clásicos como el Libro de Alexandre y el de Buen amor están mencionados constantemente junto a otros instrumentos del tipo pastoril. Sin gran autoridad, se describió más tarde al albogue como instrumento de embocadura de dos cañas que abocan en un pabellón de cuerno. De cualquier modo, resulta un instrumento del tipo óboe, como las chirimías y dulzainas, y aun la gaita zamorana, y con ello resulta natural su acoplamiento con zampoñas, caramillos y cítolas. Incluso el "finchado albogón" del que habla el Arcipreste podría ser un instrumento grave de la familia, sin duda no muy rica en posibilidades, pues que se dice en el Conde Lucanor que cierto rey moro perfeccionó el albogón dotándolo de un agujero: referencias, todas éstas, tan vagas como inciertas.

14 "Yo sé algún tanto de toscano y me precio de cantar algunas estancias del Ariosto". 
Sancho en su vida había oído hablar de albogues, aunque quizá los hubiera oído tocar en los campos, ya que no había leído libros de poesía pastoril. Don Quijote, entonces, para quien todas las palabras castellanas que comienzan con al eran palabras árabes, sacándose una explicación de la cabeza o porque tuviera conocimientos ciertos del asunto, le explica diciendo que los albogues son "unas chapas a modo de candeleros de azófar, que dando una contra otra por lo vacío y hueco hace un són, que si no muy agradable ni armónico no descontenta y viene bien con la rusticidad de la gaita y del tamborín"; y, añade el Caballero: "este nombre de albogues es morisco". De entonces acá los moriscos han olvidado la definición aunque no el instrumento, ${ }^{15}$ pero los diccionarios castellanos, incluso el de la Academia recogen la doble explicación, diciendo con Melcior, por ejemplo, lo del instrumento músico pastoril, con la descripción que no sabemos de dónde sacó este discreto comentarista y que Pedrell acepta en seguida, calcando la suya sobre la de don Quijote. Cuando los diccionarios de la lengua, más o menos académicos, lo incluyen, debe pensarse que la definición va a la cuenta de la ciencia musicológica del ingenioso hidalgo, a menos que no se mencione a otras autoridades de mayor competencia. Por ejemplo, la del Dr. Curt Sachs, quien en su Handbuch der Musikinstrumentenkunde (Leipzig, 1930), piensa que en albogue o al-buk está implícita la misma raíz que ha dado en Alemania el vocablo becken para lo que hoy llamamos platillos o címbalos, si bien ese vocablo alemán no aparece hasta el año 1742, en el Diccionario histórico y crítico de Bayle, que era un francés. ${ }^{16} \mathrm{La}$ idea de don Quijote de que chapas y albogues

15 En forma de cimbalillos de metal se denomina znoujdi en Marruecos. Hay otras muchas variedades y denominaciones.

16 Jules Rouanet, en su estudio sobre la música árabe en la Enciclopedia del Conservatorio de París (Lavignac, director, parte I, vol. v, págs. 2744 y sig.), cita a cierto Abou Said el Nisaburi, de quien no da ninguna referencia, pero que era un árabe andaluz. Según él, "el bogue es un instrumento aflautado en el que se sopla para que suene; ha sido tomado a las orquestas de danzas nocturnas de los cristianos, según opinan Zubeid y Gehnari; estos últimos añaden que el nombre de dicho instrumento debe atribuirse a la lengua de aquellos (cristianos) porque llaman a la voz, voce, y de ahí ha venido $\mathrm{Al}$ boce o $\mathrm{Al}$ boke para expresar que imita la voz humana. Las músicas cristianas se componen de bogues de los cuales se sirven para animar las batallas". J. Ribera, La Música de las Cantigas, pág. 83, dice que el albogue está descrito con pormenores en la obra de ABenjaldún Prolegómenos, u, 353 (siglo xiv). (Ibn Khaldún, 1406, Mukaddima.) Según El Secundi, citado por Ribera (Música de las Cantigas, pág. 72), en el siglo xiIr se fabricaban albogues en Sevilla (entre otros muchos instrumentos más que, desgraciadamente, Ribera traduce según su entender) junto a flautas y oboes (así denominados por Ribera). Los albogues eran muy apreciados para acompañar el canto de los zéjeles. "El albogón [mencionado por el Arcipreste como finchado albogon], tanto como el buq árabe, es, en un caso, una trompa [cuerno], y en otro una especie de saxofón [?] mejorado por el sultán andaluz Al-Hakán II ( $\uparrow$ 976). Al-Shalahi (siglo xIII) dice que los cristianos tomaron el instrumento de los árabes. Está descrito por Ibn-Khaldún y nos parece que está dibujado en las Cantigas" (H. G. Farmer, Historical Facts for the Arabian Musical Influence, London, s. f., págs. 137 y sig.). Estas referencias a otras de autores antiguos de quienes no tenemos la menor seguridad en cuanto a su ciencia o a la exactitud de sus afirmaciones me parece que carecen hoy de valor; pero como no tenemos otras nos es necesario mencionarlas. El instrumento que según eso aparecería en las Cantigas es el que Riaño reproduce en la fig. $41 \mathrm{~b}$ de su obra Critical and Bibliographical Notes on Early Spanish Music, London, 1887. Es la miniatura núm. 30 del ms. de El Escorial b-i-2. Un taf́edor cristiano sopla en un largo instrumento con embocadura y varios orificios, cortado en un ligero ángulo donde al parecer comienza el pabellón. Está acompañado por una mujer mora que toca el doble atabalillo en forma de reloj de arena que se echa por encima del hombro y que se suele entender en castellano como tamborete (Mrnéndez Pidal, Poesía juglaresca, pág. 72) y que viene a ser la derbuka árabe actual. (Puede ser de madera o de barro cocido. Se escribe de diversas maneras y cabría la posibilidad de que los vocablos adedura o hadedura fuesen lecturas defectuosas de derbuka; albardana se explicaría por su forma de albarda. En el Arcipreste se "entromete" con el panderete y las sona- 
son la misma cosa, proviene quizá de haberlos visto mencionados juntos en la Diana de Gil Polo, y en el Pastor de Fílida, de Luis Gálvez.

Sin salirnos de este repertorio pastoril y quijotesco, escuchamos a la sobrina cómo reprocha al Caballero por sus veleidades en meterse en nuevos laberintos, diciéndole que "en verdad, ya está duro el alcacel para zampoñas". Según eso, tales zampoñas serían las pipiritañas hechas con la caña tierna de la cebada, que es el alcacel. Metiéndose en honduras podría pensarse que la sobrina, de haber sido también musicóloga, quisiera decir que las cañas que se colocan en la embocadura de los instrumentos de este género no pueden ser duras, porque se hacen quebradizas, sino que han de ser tiernas y elásticas. Tanta minuciosidad no parece pertinente, y Cervantes prefiere salir del paso diciendo, por ejemplo, sin pedanterías, que los novios (cap. Xxi) "venían rodeados de mil géneros de instrumentos", con lo que dicho está que se apela al buen juicio del lector.

Respecto al uso de vocablos en su acepción genérica hay algunos en el Quijote que puede ser útil recoger. "Componer coplas" se dice en el sentido actual, en el capítulo xIr de la primera parte. Es Grisóstomo quien las "compone", pero es él mismo quien "hacía" los villancicos para la noche del Nacimiento y los autos para el día de Dios, "que los representaban los mozos de nuestro pueblo, y todos decían que eran por el cabo". Canciones y endechas son propias de pastores, amorosas las unas, desesperadas las otras. Decantado es lo mismo que cantado, y se refiere al conocido romance:

$$
\begin{gathered}
\text { Nunca fuera caballero } \\
\text { de damas tan bien servido... }
\end{gathered}
$$

Es quizá variante de discantado, aunque la significación de decantar que el Diccionario recoge es 'propalar, ponderar' (caps. xir y xirr de la primera parte). El "doloroso contrapunto" se dice en la "canción desesperada" del pobre pastor poeta por la misma razón que las flautas son tristes, es decir, por la música que tocan, porque en sí mismas ni las flautas son tristes ni los contrapuntos son dolorosos, sino por el empleo que se les da; pero ambos giros son simplemente figuras de dicción. La música "compone los ánimos descompuestos y alivia los trabajos que nacen del espíritu", dice la hermosa Lucinda (I, 28) , y para ello dejaba la rueca y se ponía "a tocar una arpa". Don Quijote gustaba de la que se tocaba a la hora de comer "sin saberse quién la canta ni adónde suena" (I, 50) y en general toda "concertada música" (II, 34). Ya hemos visto que el Caballero era músico fino en el toque y en el cante, mientras que quienes no llegaban a tanto y solamente eran "un poco músicos" se contentaban con "tocar una guitarra a lo rasgado" ( 1,51$)$, así el cabrero, aunque tuviera admiradores que dijeran "que la hacía hablar", como aquel Loaysa, y aun como el desdeñado Basilio, mientras que el tierno Anselmo, dañado de males de ausencia, se produce a la manera clásica pastoril " $\mathrm{y}$, al són de un rabel, que admirablemente toca, con versos donde muestra su buen entendimiento, cantando se queja".

jas de azófar, lo cual es congruente. Hay instrumentos análogos a los dos de las Cantigas en el Tractatus de Apocalypsi Johannis con dibujos de mediados del siglo xi. Reproducidos por Riaño, ob. cit., fig. 39). 
En Rojas se lee de varias maneras el vocablo bogiganga, boxiganga o boiiganga. Entre los farsantes que han de representar el auto de las Cortes de la Muerte, "uno de la compañía, que venía vestido de bogiganga, con muchos cascabeles, y en la punta de un palo traía tres vegigas de vaca hinchadas", hace ver que bogiganga es nombre aplicado a una persona como los fous o fols medievales, que de tan antigua estirpe griega y latina podían presumir. "El cual moharracho -añade el texto-, llegándose a don Quijote, comenzó a esgrimir el palo y a sacudir el suelo con las vegigas y a dar grandes saltos sonando los cascabeles", al igual de los cofrades franceses de la Mère-folle y otras cofradías en auge desde el siglo xin al xvi.Lix Los espectadores se conocen como aspetatores en el cap. xix de la parte segunda, y no es Sancho quien habla. $Y$ aquellos cleriguillos que cantaban su misa al asno en tiempos lejano's $\mathbf{x}$ habrían admirado el torneo de rebuznos en el cap. xxv, "a su tiempo y compás", según se dice, en abundancia de "los dejos, muchos y apresurados", como en la mejor copla de cante hondo...

ADOLFO SALAZAR

El Colegio de México. 